University of South Florida

DIGITAL COMMONS

Digital Commons @ University of

@ UNIVERSITY OF SOUTH FLORIDA

South Florida

$12-5-2007$

\title{
Reconstructing Twentieth-Century Sea Surface Temperature Variability in the Southwest Pacific: A Replication Study Using Multiple Coral Sr/Ca Records from New Caledonia
}

\author{
Kristine L. DeLong \\ University of South Florida \\ Terrence M. Quinn \\ University of Texas, quinn@marine.usf.edu \\ Frederick W. Taylor \\ University of Texas
}

Follow this and additional works at: https://digitalcommons.usf.edu/msc_facpub

Part of the Marine Biology Commons

\section{Scholar Commons Citation}

DeLong, Kristine L.; Quinn, Terrence M.; and Taylor, Frederick W., "Reconstructing Twentieth-Century Sea Surface Temperature Variability in the Southwest Pacific: A Replication Study Using Multiple Coral Sr/Ca Records from New Caledonia" (2007). Marine Science Faculty Publications. 115.

https://digitalcommons.usf.edu/msc_facpub/115

This Article is brought to you for free and open access by the College of Marine Science at Digital Commons @ University of South Florida. It has been accepted for inclusion in Marine Science Faculty Publications by an authorized administrator of Digital Commons @ University of South Florida. For more information, please contact digitalcommons@usf.edu. 


\title{
Reconstructing twentieth-century sea surface temperature variability in the southwest Pacific: A replication study using multiple coral $\mathrm{Sr} / \mathrm{Ca}$ records from New Caledonia
}

\author{
Kristine L. DeLong, ${ }^{1}$ Terrence M. Quinn, ${ }^{2,3}$ and Frederick W. Taylor ${ }^{2}$ \\ Received 27 February 2007; revised 27 June 2007; accepted 20 July 2007; published 5 December 2007.
}

[1] Coral-based climate reconstructions typically have not used multiple cores from a region to capture and replicate a climate signal largely because of concerns of coral conservation, analytical expense, and time constraints. Coral $\mathrm{Sr} / \mathrm{Ca}$ reproducibility through the twentieth century was investigated using three intracolony and three intercolony coral records from the reefs offshore of Amédée Island, New Caledonia. Different sampling resolutions were examined in coral $\mathrm{Sr} / \mathrm{Ca}$ (fortnightly and monthly) and $\delta^{18} \mathrm{O}$ (fortnightly, monthly, and seasonally) as well as similar scale subsampling of the daily in situ sea surface temperature (SST) record. The mean coral $\mathrm{Sr} / \mathrm{Ca}, \delta^{18} \mathrm{O}$, and SST values do not change as a function of sampling resolution. The coral $\mathrm{Sr} / \mathrm{Ca}$ signal is highly reproducible; the average absolute offset between coeval monthly $\mathrm{Sr} / \mathrm{Ca}$ determinations between any two coral time series is $0.035 \pm 0.026 \mathrm{mmol} / \mathrm{mol}(1 \sigma)\left(\sim 0.65^{\circ} \mathrm{C}\right)$, which is less than twice the analytical precision of the coral $\mathrm{Sr} / \mathrm{Ca}$ measurements. The stack average of the monthly coral $\mathrm{Sr} / \mathrm{Ca}$ variations and monthly anomalies are significantly correlated with monthly in situ SST (1967-1992; $r=-0.96$ and -0.64 , respectively; $p<0.05$; and $n=302)$ and $1^{\circ}$ grid monthly SST data product $(1900-1999 ; r=-0.95$ and -0.56 , respectively; $p<0.05$; and $n=1198$ ). The coral $\mathrm{Sr} / \mathrm{Ca}-\mathrm{SST}$ reconstruction exhibits interannual and decadal- timescale fluctuations that exceed those observed in the gridded SST record, which may reflect true differences between SST at a shallow reef site and those averaged over a $1^{\circ}$ grid box or inadequacies in the methodology used to create the gridded SST product when few observations are available. A warming trend of $\sim 0.6^{\circ} \mathrm{C}$ is observed in the twentieth century coral $\mathrm{Sr} / \mathrm{Ca}-\mathrm{SST}$ record.

Citation: DeLong, K. L., T. M. Quinn, and F. W. Taylor (2007), Reconstructing twentieth-century sea surface temperature variability in the southwest Pacific: A replication study using multiple coral Sr/Ca records from New Caledonia, Paleoceanography, 22, PA4212, doi:10.1029/2007PA001444.

\section{Introduction}

[2] Climate reconstructions using corals are typically based on the geochemical variations of a single core, which may be unique to that coral colony or may reflect largescale climate variability [Cook, 1995]. Lough [2004] compared 20 previously published coral records from the Pacific and found inconsistencies between the records leading them to question the validity of interpreting a single, long coral record because of the possibility of nonclimatic influences dominating a geochemical record. Dendroclimatic studies typically utilize multiple cores from a single tree and multiple cores from many trees to minimize biological variability, to cross-date the age model, and to perform an assessment of the climate signal; few coral-based climate studies have utilized this level of replication. The coralbased studies that include replication have primarily focused

\footnotetext{
${ }^{1}$ College of Marine Science, University of South Florida, St. Petersburg, Florida, USA.

${ }^{2}$ Institute for Geophysics, Jackson School of Geosciences, University of Texas at Austin, Austin, Texas, USA.

${ }^{3}$ Department of Geological Sciences, Jackson School of Geosciences, University of Texas at Austin, Austin, Texas, USA.
}

Copyright 2007 by the American Geophysical Union. 0883-8305/07/2007PA001444 on climate signal verification at either the local level [e.g., Alibert and McCulloch, 1997; Felis et al., 2003; Stephans et al., 2004] or the regional level [e.g., Hendy et al., 2002; Linsley et al., 2006]. Mean coral $\mathrm{Sr} / \mathrm{Ca}$ differences for Porites spp. in local replication studies range from $0.01 \mathrm{mmol} / \mathrm{mol}\left(\sim 0.2^{\circ} \mathrm{C}\right)$ for monthly resolved records in New Caledonia [Stephans et al., 2004] to $0.14 \mathrm{mmol} / \mathrm{mol}$ $\left(\sim 2.5^{\circ} \mathrm{C}\right)$ for annually resolved records in Fiji [Linsley et al., 2006], and $0.2 \mathrm{mmol} / \mathrm{mol}\left(\sim 3.3^{\circ} \mathrm{C}\right)$ for bimonthly resolved records in the Red Sea [Felis et al., 2004]. The large mean differences in coral $\mathrm{Sr} / \mathrm{Ca}$ were attributed to growth rate variability [Felis et al., 2003, 2004] or some unknown complicating factor [Linsley et al., 2006].

[3] This study expands upon previous coral-based climate studies offshore of Amédée Island, New Caledonia, [Quinn et al., 1996, 1998; Crowley et al., 1999; Stephans et al., 2004] by examining five coral cores, three intracolony and three intercolony, for the period 1900-1999. The goals of this study include: (1) expanding the sample resolution test to include coral $\mathrm{Sr} / \mathrm{Ca}$ and higher sampling resolution, (2) extending the coral $\mathrm{Sr} / \mathrm{Ca}$ reproducibility test to span the entire twentieth century, (3) assessing the stack coral $\mathrm{Sr} / \mathrm{Ca}$ record with dendrochronology methods, (4) comparing coral $\mathrm{Sr} / \mathrm{Ca}$ variations with in situ $\mathrm{SST}$ variations, and 


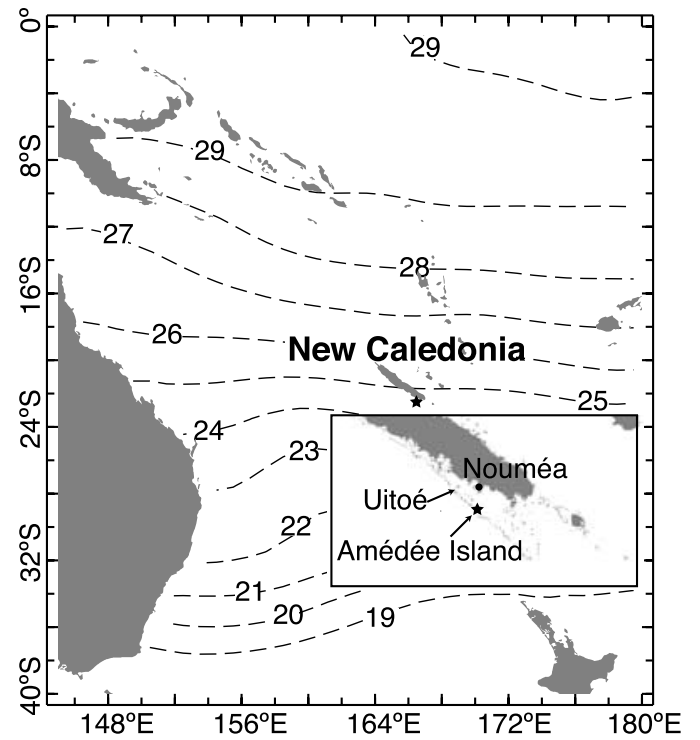

Figure 1. New Caledonia, located in the southwest tropical Pacific Ocean. Contours are annual average SST $\left({ }^{\circ} \mathrm{C}\right)$ [Levitus and Boyer, 1994]. Amédée Island $\left(22^{\circ} 28.5^{\prime} \mathrm{S}\right.$, $166^{\circ} 28.0^{\prime} \mathrm{E}$; noted by star) is located off the southwest coast of New Caledonia, $20 \mathrm{~km}$ south of Nouméa, behind the barrier reef and within the Boulari Pass. Inset map from ReefBase shows coral reef distribution and location of study sites (http://reefgis.reefbase.org/mapper.asp).

(5) verifying the coral $\mathrm{Sr} / \mathrm{Ca}-\mathrm{SST}$ calibration for a longer time interval against an independent SST data set.

\section{Study Area}

[4] New Caledonia $\left(20^{\circ} 00^{\prime}-22^{\circ} 30^{\prime} \mathrm{S}, 163^{\circ} 30^{\prime}-167^{\circ} 30^{\prime} \mathrm{E}\right)$ is located in the southwest tropical Pacific Ocean (Figure 1) and has a tropical climate influenced by the annual variations in latitude of the South Pacific Convergence Zone (SPCZ) to the north and the subtropical anticyclonic belt to the south [Morliere and Rebert, 1986; Pesin et al., 1995]. New Caledonia experiences warm wet summers (January to March), when the SPCZ is in its southernmost location and cool dry winters (July to September) when the SPCZ is in its northernmost location [Morliere and Rebert, 1986; Pesin et al., 1995].

[5] Amédée Island $\left(22^{\circ} 28.5^{\prime} \mathrm{S}, 166^{\circ} 28.0^{\prime} \mathrm{E}\right)$ is located off the southwest coast of New Caledonia, $20 \mathrm{~km}$ south of Nouméa, behind the barrier reef and adjacent to the Boulari Pass (Figure 1). The reefs offshore of Amédée Island are well bathed by open-ocean waters and the reefs do not appear to be subjected to freshwater input from the mainland [Quinn et al., 1996; Stephans et al., 2004; Montaggioni et al., 2006]. The French research group, Institut de Recherche pour le Developpement-Etudes Climatiques de l'Océan Pacifique tropical (IRD-ECOP) has collected daily (7:00 A.M.) bucket measurements of SST $\left( \pm 0.2^{\circ} \mathrm{C}\right)$ measurements offshore of Amédée Island (5 m depth) since 1967 [Delcroix and Lenormand, 1997] making this location well suited for a coral-based climate reconstruction. In situ SST
(IRD SST) varies with a regular annual cycle and has a mean summer SST (January, February, and March) of $25.7 \pm 0.7^{\circ} \mathrm{C}$ $(1 \sigma)$, a mean winter SST (July, August, and September) of $21.4 \pm 0.6^{\circ} \mathrm{C}(1 \sigma)$, and annual average SST of $23.5 \pm 1.8^{\circ} \mathrm{C}$ $(1 \sigma)$.

[6] Previous studies have noted that monthly IRD SST is cooler $\left(1.2\right.$ to $\left.1.5^{\circ} \mathrm{C}\right)$ than both open-ocean SST measured from outside the barrier reef [Hénin et al., 1984; Delcroix and Lenormand, 1997] and gridded monthly SST databases (i.e., GISST2 [Parker et al., 1995], IGOSS [Reynolds and Smith, 1994], and HadISST1.1 [Rayner et al., 2003]) [Crowley et al., 1999; Corrège, 2006]. A portion of the observed differences in monthly SST may be due to a bias introduced by measuring daily SST at 7:00 A.M. Amédée Island has a mean diurnal cycle of an almost linear increase of $0.1^{\circ} \mathrm{C}$ per hour between 5:00 A.M. and 3:00 P.M. [Delcroix and Lenormand, 1997], which results in an $\sim 0.2^{\circ} \mathrm{C}$ bias for SST measurements at 7:00 A.M. versus a mean daily SST. Another source of potential bias is bucket measurements versus deployed automatic measurements. In June 1997, an automatic recorder was installed offshore of Amédée Island which records SST every $15 \mathrm{~min}$. The difference between the average of the daily bucket measurements and the average of the mean daily automatic measurements is $0.9^{\circ} \mathrm{C}$ for the concurrent period (18 June 1997 to 31 December 1999). Additionally, there is evidence of local upwelling events along the western barrier reefs of New Caledonia that persist for periods of days to weeks that have been observed in satellite infrared images and hourly SST measurements on the oceanside of the reef at Uitoé, $36 \mathrm{~km}$ northwest of Amédée Island (Figure 1) [Hénin and Cresswell, 2005; Alory et al., 2006]. Examination of the daily SST measurements from Amédée Island showed the same upwelling/cooling events noted by Hénin and Cresswell [2005]; however, the magnitude is reduced (compare $3^{\circ}$ to $4^{\circ} \mathrm{C}$ versus $5^{\circ} \mathrm{C}$ ). The magnitude of these cool events diminishes to $<1^{\circ} \mathrm{C}$ when the daily SST is averaged to monthly. The combination of measurement biases and upwelling events may explain the differences observed between IRD SST and open-ocean temperature measurements including monthly SST databases (discussed further in section 5.5).

\section{Methods}

\subsection{Coral Records Examined}

[7] The Porites lutea colonies sampled in this study were located in $<3 \mathrm{~m}$ of water within the Boulari Pass, which is adjacent to Amédée Island, New Caledonia $\left(22^{\circ} 28.5^{\prime} \mathrm{S}\right.$, $166^{\circ} 28.0^{\prime} \mathrm{E}$, Figure 1) [Quinn et al., 1996; Stephans et al., 2004]. Four cores (92-PAA1, 92-PAA2, 92-PAC1, and 92PAD1) were recovered in July 1992 and a fifth core (99-PAA) was recovered in December 1999. Three cores (92-PAA1, 92-PAA2, and 99-PAA) were recovered from the same massive coral colony (PAA) and the other two cores (92-PAC1 and 92-PAD1) were collected from nearby coral colonies $(\sim 0.5 \mathrm{~km})$.

[8] Sections from four of the Amédée Island cores examined in this study have been sampled for seasonally and monthly resolved isotopes in previous studies [Quinn et al., 
Table 1. Resolution Summary

\begin{tabular}{llcl}
\hline \multicolumn{1}{c}{ Core } & Geochemistry & Resolution, samples/cm & \multicolumn{1}{c}{ Source } \\
\hline 92-PAA1 & $\delta^{18} \mathrm{O}, \delta^{13} \mathrm{C}$ & 4 (seasonally) & Quinn et al. $[1998]$ \\
92-PAC1 & $\mathrm{Sr} / \mathrm{Ca}, \delta^{18} \mathrm{O}, \delta^{13} \mathrm{C}$ & 16 (monthly) & Stephans et al. [2004] and this study \\
92-PAD1 & $\mathrm{Sr} / \mathrm{Ca}, \delta^{18} \mathrm{O}, \delta^{13} \mathrm{C}$ & 16 (monthly) & Stephans et al. [2004] and this study \\
99-PAA & $\mathrm{Sr} / \mathrm{Ca}, \delta^{18} \mathrm{O}, \delta^{13} \mathrm{C}$ & 16 (monthly) & Stephans et al. [2004] and this study \\
92-PAA1 & $\mathrm{Sr} / \mathrm{Ca}, \delta^{18} \mathrm{O}, \delta^{13} \mathrm{C}$ & 15 (monthly) & this study \\
92-PAA2 & $\mathrm{Sr} / \mathrm{Ca}$ & 12 (monthly) & this study \\
92-PAA1-B & $\mathrm{Sr} / \mathrm{Ca}, \delta^{18} \mathrm{O}, \delta^{13} \mathrm{C}$ & 30 (fortnightly) & this study \\
\hline
\end{tabular}

1996, 1998; Crowley et al., 1999; Stephans et al., 2004] and for monthly resolved coral $\mathrm{Sr} / \mathrm{Ca}$ in two previous studies [Quinn and Sampson, 2002; Stephans et al., 2004] for the period 1967-1992 (Table 1 and Figure 2). This study contributes to the suite of Amédée Island records by 1) determining fortnightly resolved coral $\mathrm{Sr} / \mathrm{Ca}, \delta^{18} \mathrm{O}$, and $\delta^{13} \mathrm{C}$ variations from 92-PAA1-B to compare with monthly and seasonal variations, 2) replicating monthly resolved coral $\mathrm{Sr} / \mathrm{Ca}$ variations along parallel paths on 92-PAC1-A, 92-PAA1-A, and 92-PAA1-B, 3) determining monthly coral $\mathrm{Sr} / \mathrm{Ca}$ variations from $92-\mathrm{PAA} 1$ and $92-\mathrm{PAA} 2$ for the entire twentieth century, and 4) extending the monthly resolved coral $\mathrm{Sr} / \mathrm{Ca}$ record for $92-\mathrm{PAD} 1$ to 1937 and 92-PAC1 to 1950 .

\subsection{Coral Sampling}

[9] The coral cores used in this study were collected by drilling a 3.5-m-long, 8-cm-diameter core along the primary vertical growth axis of the coral colony and then these cores were sliced vertically to 5-mm-thick slabs. Annual density bands visible on $\mathrm{X}$ rays of these slabs were used to determine sampling paths and sampling resolution (Figure 2). The optimal sampling path is perpendicular to the annual density bands; however, the direction of growth in the corallites may be different on either side of the coral slab because of the small size of the corallites in Porites lutea. The sampling path was determined by locating the near vertical annual density bands on the $\mathrm{X}$ rays and examining the coral slab under magnification to determine the growth direction of the corallites. The coral slabs were drilled using a continuous routing program on a computer-aided triaxial sampler described in detail by Quinn et al. [1996]. This study sampled the core 92-PAA1 parallel to the path used in previous studies (Figure 2) with a 1.4-mm-diameter drill bit; sample powders were collected every $0.70 \mathrm{~mm}$ (approximately monthly resolution) and every $0.30 \mathrm{~mm}$ (approximately fortnightly resolution; see Table 1 for resolution summary by core).

\subsection{Geochemical Analysis}

[10] Elemental ratio $(\mathrm{Sr} / \mathrm{Ca})$ and stable isotopic $\left(\delta^{18} \mathrm{O}\right.$ and $\left.\delta^{13} \mathrm{C}\right)$ measurements were made from splits of the homogenized coral sample using instrumentation at the University of South Florida. Sr/Ca measurements were made using a PerkinElmer Optima 4300 Dual View Inductively Coupled Plasma Optical Emission Spectrometer (ICP-OES) using the drift correction method described by Schrag [1999]. Coral powder samples $(90-236 \mu \mathrm{g})$ were diluted in a volume of $2 \%$ trace metal grade $\mathrm{HNO}_{3}$ to obtain a target sample solution having $\sim 20 \mathrm{ppm}$ calcium. The overall analytical precision $(1 \sigma)$ of the laboratory internal gravimetric standard (IGS) used for the drift correction was $\pm 0.010 \mathrm{mmol} /$ mol $(n=730 ; 0.11 \%$ relative standard deviation (RSD)) based on measurements before and after each sample. An additional estimate of precision was determined using a homogenized powder of Porites lutea (PL), which was analyzed every fifth sample. The overall precision $(1 \sigma)$ of the coral standard was $\pm 0.017 \mathrm{mmol} / \mathrm{mol}(n=776 ; 0.19 \%$ RSD). $\mathrm{Mg} / \mathrm{Ca}$ determinations were conducted concurrent with $\mathrm{Sr} / \mathrm{Ca}$ determinations with an overall analytical precision of $\pm 0.017 \mathrm{mmol} / \mathrm{mol}(1 \sigma, n=725)$. The absolute value of the $\mathrm{Sr} / \mathrm{Ca}$ for the IGS and PL coral standard has been confirmed by thermal ionization mass spectrometry at the University of Minnesota Isotope Laboratory.

[11] Stable isotopes were measured using a ThermoFinnigan Delta Plus XL dual-inlet mass spectrometer with Kiel Carbonate III preparation device. Coral powder $(40-80 \mu \mathrm{g})$ was reacted with phosphoric acid at $70^{\circ} \mathrm{C}$ in the Kiel device to release $\mathrm{CO}_{2}$ gas for analysis in the mass spectrometer. The overall analytical precision $(1 \sigma)$ determined by analysis of NBS19 run in conjunction with coral samples was $\pm 0.06 \%$ and $\pm 0.04 \%$ for $\delta^{18} \mathrm{O}$ and $\delta^{13} \mathrm{C}$, respectively. Isotopic ratios are reported in delta $(\delta)$ notation relative to Vienna Pee Dee Belemnite (VPDB).

\subsection{Establishing Chronology}

[12] Two methods were employed to establish the age model for the individual coral records: counting annual density bands on the coral $\mathrm{X}$ rays and aligning coral $\mathrm{Sr} /$ Ca variations to a SST record. Quinn et al. [1996, 1998] generated the original age model for the core 92-PAA1 using monthly and seasonal coral $\delta^{18} \mathrm{O}$ variations. This study generated the age model using coral $\mathrm{Sr} / \mathrm{Ca}$ variations as a result of the higher correlation of coral $\mathrm{Sr} / \mathrm{Ca}$ with IRD SST [Quinn and Sampson, 2002; Stephans et al., 2004]. The conversion from depth to time domain was achieved by matching coral $\mathrm{Sr} / \mathrm{Ca}$ maxima (minima) to SST minima (maxima) for each annual cycle using AnalySeries software [Paillard et al., 1996]. In order to maximize alignment between records, additional tie points were utilize to match midspring and midautumn points between coral $\mathrm{Sr} / \mathrm{Ca}$ and SST record. The SST record used for alignment is a composite of IRD SST from 1967-2000, and the $1^{\circ}$ gridded SST data set extracted from the HadISST1.1 database [Rayner et al., 2003] centered on $22.5^{\circ} \mathrm{S}, 166.5^{\circ} \mathrm{E}$ (referred to as HadISST_AI) from 1900-1967 which was adjusted to match IRD ${ }^{-}$SST mean and variance (referred to as adjHadISST_AI; adjHadISST_AI = HadISST_AI(1.074 2.989); see section 2 ). The $\mathrm{Sr} / \mathrm{Ca}$ age model for each core was applied to the other geochemical records. The geo- 

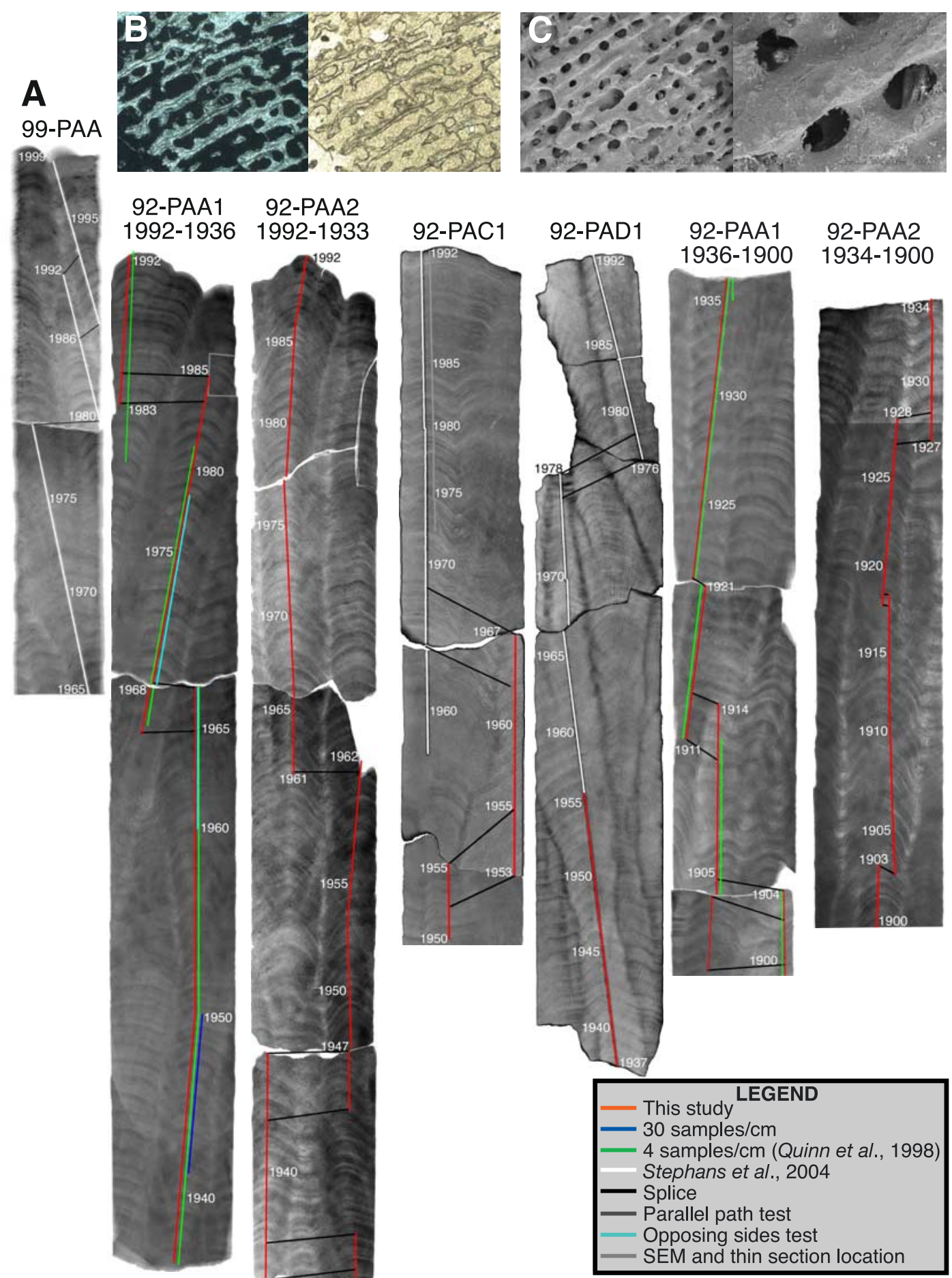

Figure 2. (a) Positive X-ray images of five Porites lutea coral slabs from cores collected offshore of Amédée Island, New Caledonia. Core identifiers appear across the top and years are noted in white down each core. Sampling paths are approximately parallel to the coral's vertical central growth axis. Sampling paths used in this study and previous studies are indicated by solid approximately vertical lines and are labeled with different colors. (b) Thin section photomicrographs viewed under (left) cross-polarized light plane and (right) transmitted light (field of view equals $2.6 \mathrm{~mm}$ in each). (c) Scanning electron microscope (SEM) images magnified by (left) 45 and (right) 200. Thin sections and SEM images were examined from the top of the core 92-PAA1 for the presence of secondary minerals; none were observed. 

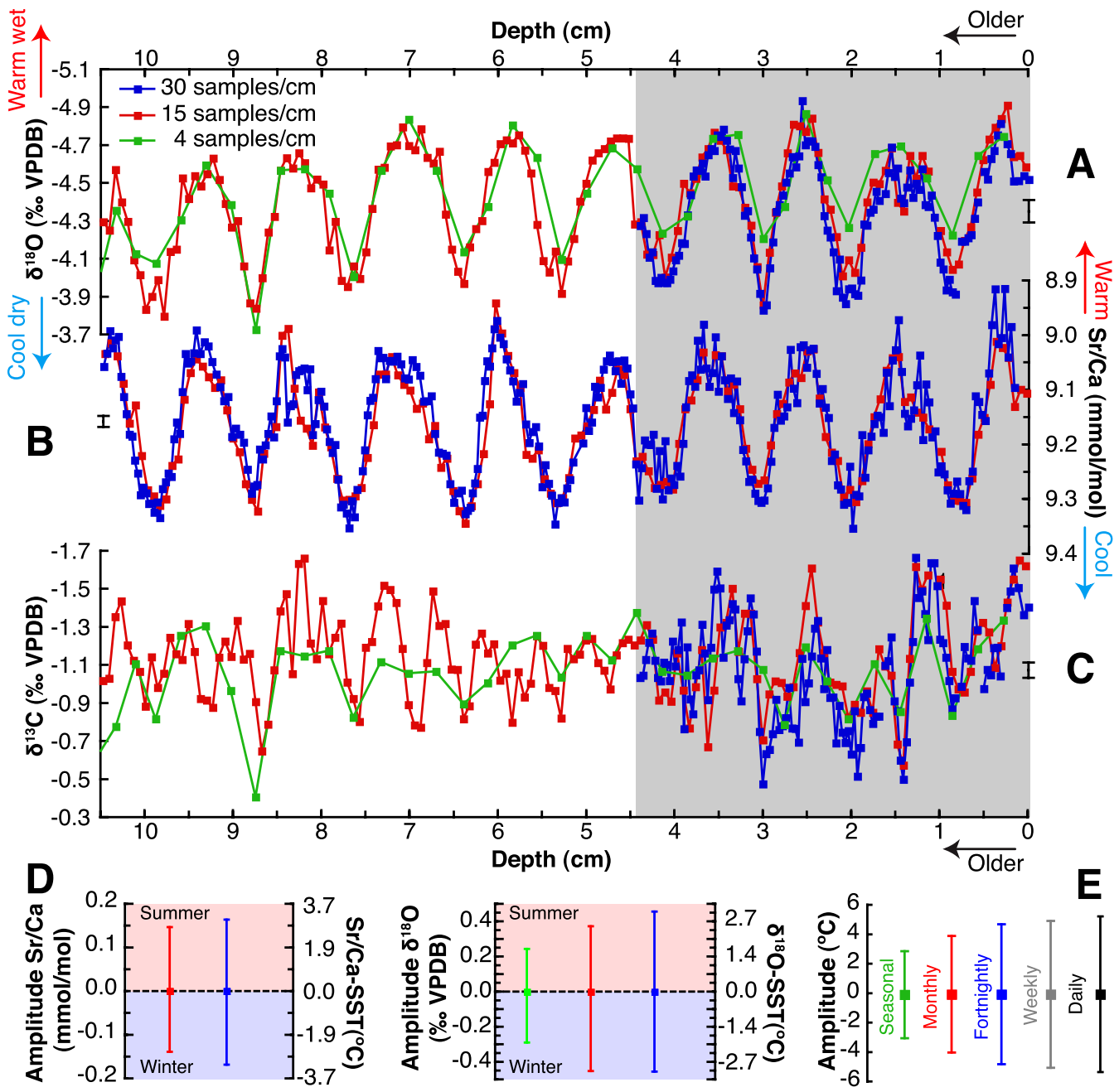

Figure 3. Sampling resolution comparison between parallel paths. The coral section 92-PAA1-B was originally sampled at 4 samples/cm (seasonally) by Quinn et al. [1998]. This study sampled the coral on either side of the Quinn et al. [1998] path $(<0.5 \mathrm{~cm})$ using increasing resolution: $15 \mathrm{samples} / \mathrm{cm}$ (monthly) and 30 samples/cm (fortnightly) (see Figure 2 for sampling path location). Coral samples analyzed for (a) $\delta^{18} \mathrm{O}$, (b) $\mathrm{Sr} / \mathrm{Ca}$, and (c) $\delta^{13} \mathrm{C}$. Error bars represent analytical precision $(1 \sigma)$, each positioned on their respective means. The fortnightly $\mathrm{Sr} / \mathrm{Ca}$ depth was adjusted to align with monthly $\mathrm{Sr} /$ $\mathrm{Ca}$ variations, and depth adjustments were applied to other geochemical records. The same method of adjustments was applied to the seasonal records using monthly $\delta^{18} \mathrm{O}$ depth. Comparisons are based on depths common to all resolutions (gray rectangle). Mean coral $\mathrm{Sr} / \mathrm{Ca}, \delta^{18} \mathrm{O}$, and $\delta^{13} \mathrm{C}$ values do not change significantly as a function of sampling resolution. (d) Mean $\mathrm{Sr} / \mathrm{Ca}(n=10)$ and $\delta^{18} \mathrm{O}(n=4)$ summer and winter amplitudes determined for each sampling resolution. (e) Mean amplitude for IRD SST filtered to various resolutions.

chemical and depth records were linearly resampled to even monthly intervals and the monthly depth record was used to calculate annual extension rate.

[13] Cross dating was employed to create the master chronology and to verify the chronology of the individual records. Advantages of cross dating include improved alignment between discontinuous sampling paths and the ability to assess locally absent years between core sections (Figure 2). Cross dating was achieved by matching the coral $\mathrm{Sr} / \mathrm{Ca}$ variations between the cores. The alignment of coral $\mathrm{Sr} / \mathrm{Ca}$ variations in depth space is cumbersome because of different sampling resolutions, variations in extension rates, and possible locally absent years between core sections. First, each core section was aligned to the SST record using a best guess age assignment determined from the density band chronology, next each core section was visually aligned with concurrent core sections, and then the age assignments were adjusted accordingly. The master chronology was generated after all the cores were aligned and gaps between core sections were assessed for locally absent years. The final age model for each core was verified against the annual density bands (Figure 2) and SST record. 


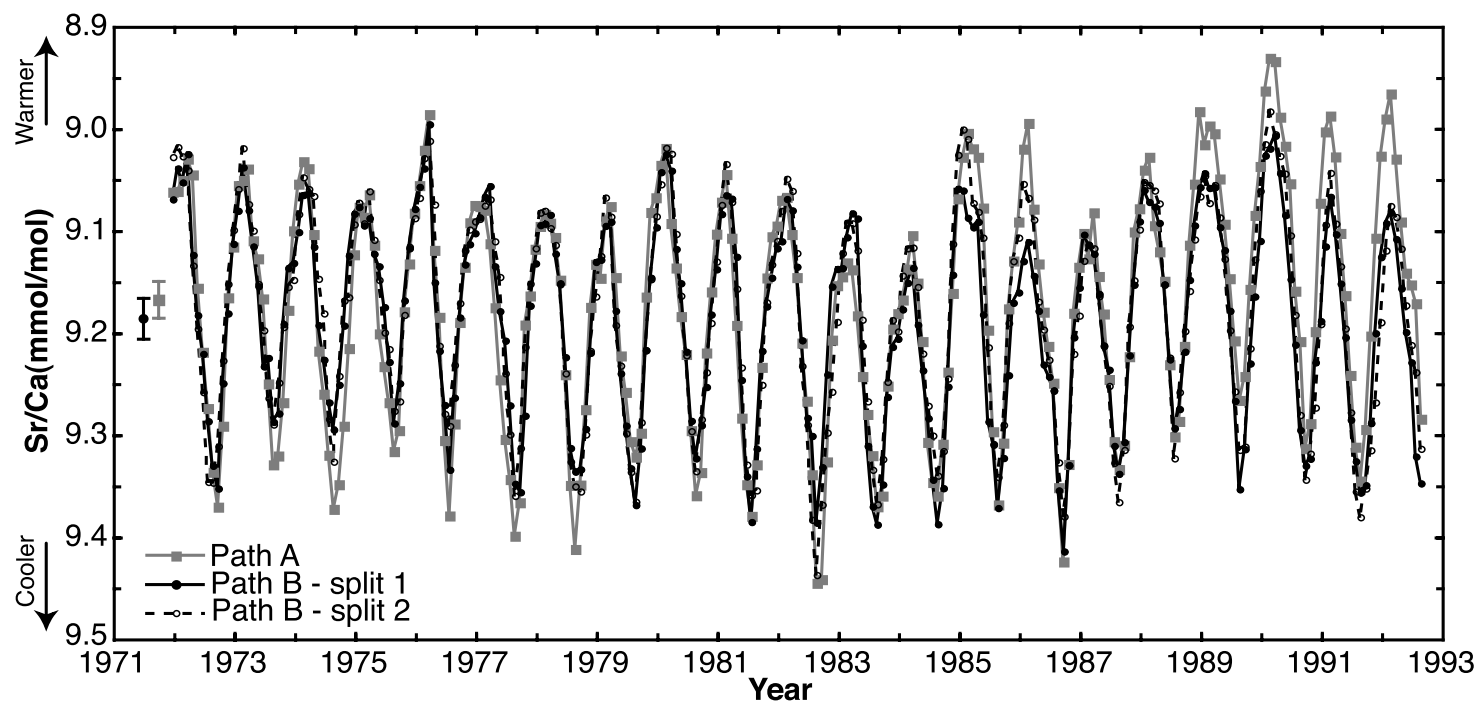

Figure 4. Coral $\mathrm{Sr} / \mathrm{Ca}$ replication between parallel sampling paths $\sim 0.5 \mathrm{~cm}$ apart. Path B was sampled parallel to the Stephans et al. [2004] path on 92-PAC1 (Figure 2); both paths were sampled at 16 samples/ $\mathrm{cm}$. Duplicate $\mathrm{Sr} / \mathrm{Ca}$ determinations were performed from splits of samples from path $\mathrm{B}$, and correlation is high between duplicates and parallel paths ( $r=0.96$ and 0.93 , respectively; $p<0.05$; and $n=249$ ). Error bars represent analytical precision $( \pm 0.018 \mathrm{mmol} / \mathrm{mol}, 2 \sigma$, path A [Stephans et al., 2004]), each positioned on their respective means.

\subsection{Data Analysis}

[14] Differences between means and variances were tested using two approaches; the classical Student's $t$ test and $F$ test, which assumes independence and normal distribution of the errors, and Monte Carlo simulation using equivalent degrees of freedom determined by the Runs test. Covariance was determined using two approaches: the Pearson Product Moment correlation coefficients, and Monte Carlo simulation. The transfer function between coral $\mathrm{Sr} / \mathrm{Ca}$ and SST was determined by linear regression using a generalized least squares, which utilizes maximum likelihood estimation (MLE) method of York and Evensen [2004].

\section{Results}

[15] The fidelity of the coral records from New Caledonia was confirmed by examining the coral samples for evidence of alteration, estimating annual extension rates, and crossdating the multiple coral records. Examination of scanning electron microscope images (SEM) and petrographic thin sections of 92-PAA1 found no evidence of secondary minerals (Figures $2 \mathrm{~b}$ and $2 \mathrm{c}$ ). Extension rates averaged $\sim 1.0 \mathrm{~cm} / \mathrm{a}$ (where a is years) in all cores and efforts were made to avoid sampling in regions where the annual density bands were $<0.6 \mathrm{~cm}$ in length. The cross-dating procedure utilized in this study resulted in adjustments to the chronologies established in previous studies (one false year and one missing year for 92-PAA1 [Quinn et al., 1998] and two false years for 92-PAD1 [Stephans et al., 2004]).

\subsection{Multiple Sampling Resolutions}

[16] The effect of different sampling resolutions in coral $\mathrm{Sr} / \mathrm{Ca}$ (fortnightly and monthly; Table 1 ) and $\delta^{18} \mathrm{O}$ and $\delta^{13} \mathrm{C}$ (fortnightly, monthly, and seasonally; Table 1) was investi- gated and the results were compared to similar scale subsampling of the daily SST time series from this site (Figure 3). The comparisons between different geochemical resolutions were conducted in core depth space. The difference between coral $\mathrm{Sr} / \mathrm{Ca}$ determinations sampled with monthly and fortnightly resolution is within analytical precision of the $\mathrm{Sr} / \mathrm{Ca}$ measurement $( \pm 0.010 \mathrm{mmol} / \mathrm{mol}, 1 \sigma)$. The standard deviation $(1 \sigma)$ in the coral $\mathrm{Sr} / \mathrm{Ca}$ records changes from $\pm 0.101 \mathrm{mmol} / \mathrm{mol}$ (fortnightly sampling) to $\pm 0.094 \mathrm{mmol} / \mathrm{mol}$ (monthly sampling), a $6.9 \%$ reduction with respect to fortnightly resolution. The standard deviation $(1 \sigma)$ in the coral $\delta^{18} \mathrm{O}$ records changes from $\pm 0.27 \%$ (fortnightly sampling) to $\pm 0.26 \%$ (monthly sampling) to $\pm 0.22 \%$ (seasonal sampling), a $4.0 \%$ reduction between fortnightly and monthly sampling. The standard deviation $(1 \sigma)$ in the coral $\delta^{13} \mathrm{C}$ records changes from $\pm 0.27 \%$ (fortnightly sampling) to $\pm 0.26 \%$ (monthly sampling) to $\pm 0.19 \%$ o (seasonal sampling), a $5.0 \%$ reduction between fortnightly and monthly sampling. Overall, mean coral $\mathrm{Sr} /$ $\mathrm{Ca}, \delta^{18} \mathrm{O}$, and $\delta^{13} \mathrm{C}$ values do not change significantly as a function of sampling resolution. The standard deviation $(1 \sigma)$ in the daily IRD SST changes from $\pm 2.0^{\circ} \mathrm{C}$ (daily sampling) to $\pm 1.9^{\circ} \mathrm{C}$ (fortnightly sampling) to $\pm 1.8^{\circ} \mathrm{C}$ (monthly sampling) to $\pm 1.7^{\circ} \mathrm{C}$ (seasonal sampling), a $1.7 \%$ reduction between fortnightly and monthly sampling and there is no change in the mean IRD SST value as a function of sampling resolution.

\subsection{Replication of Coral $\mathrm{Sr} / \mathrm{Ca}$ Variations}

[17] Replication tests were conducted on increasing spatial and temporal scales to assess the reproducibility of our coral $\mathrm{Sr} / \mathrm{Ca}$ records. At the individual sample scale, duplicate $\mathrm{Sr} / \mathrm{Ca}$ determinations of coral powder confirmed coral samples are homogeneous (Figure 4). The average of the 


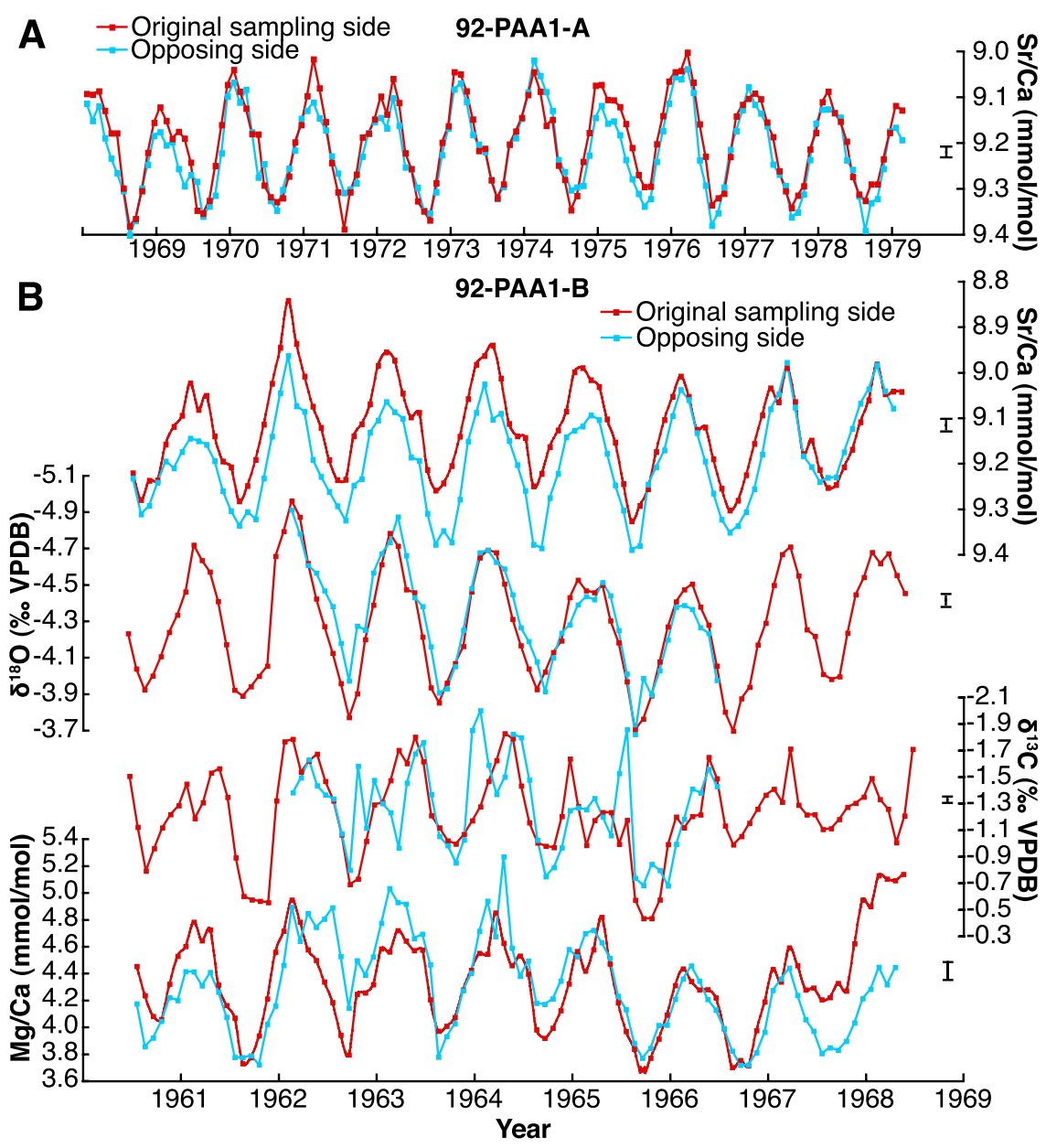

Figure 5. (a) Monthly coral $\mathrm{Sr} / \mathrm{Ca}$ determinations sampled on opposing sides of the coral slab $(\sim 0.5 \mathrm{~cm}$ thick) 92-PAA1-A (Figure 2). Means and standard deviations are not significantly different. (b) Monthly coral $\mathrm{Sr} / \mathrm{Ca}$ determinations sampled on opposing sides of the coral slab 92-PAA1-B (Figure 2). The agreement between the first two $\mathrm{Sr} / \mathrm{Ca}$ cycles (1966-1968) is good; however, from 1960 to 1966 the two paths diverge $\left(\operatorname{avg}_{\mathrm{abs}}=0.093 \mathrm{mmol} / \mathrm{mol}\right)$. Additional coral geochemical variations $\left(\delta^{18} \mathrm{O}, \delta^{13} \mathrm{C}\right.$, and $\mathrm{Mg} /$ Ca) from 92-PAA1-B were compared, and no offset was observed. The trace elemental and isotopic ratios for the original sampling side are from two different sampling paths (Figure 2); trace elements were measured by this study, and isotopes were measured by Quinn et al. [1998]. Error bars represent respective analytical precision $(1 \sigma)$.

absolute differences ( avg $_{\text {abs }}$ ) between duplicate monthly coral $\mathrm{Sr} / \mathrm{Ca}$ determinations $(0.022 \mathrm{mmol} / \mathrm{mol})$ is $<2 \sigma$ of the magnitude of analytical precision $( \pm 0.020 \mathrm{mmol} / \mathrm{mol}$, $2 \sigma$, or magnitude of $0.040 \mathrm{mmol} / \mathrm{mol}$ ). The next spatial scale tested reproducibility for a 20 -a interval between parallel sampling paths spaced $\sim 0.5 \mathrm{~cm}$ apart on 92-PAC1-A where this study sampled next to the path sampled by Stephans et al. [2004] (Figures 2 and 4). The means and standard deviations between the parallel paths are not significantly different and correlation between the paths is high $(r=0.93, p<0.05, n=249)$. The avg $_{\text {abs }}$ between parallel paths for coeval monthly coral $\mathrm{Sr} / \mathrm{Ca}$ determinations $(0.031 \mathrm{mmol} / \mathrm{mol})$ is $<2 \sigma$ of the magnitude of analytical precision $( \pm 0.018 \mathrm{mmol} / \mathrm{mol}, 2 \sigma$ [Stephans et al., 2004$]$ and $\pm 0.020 \mathrm{mmol} / \mathrm{mol}, 2 \sigma$, or magnitude of $0.040 \mathrm{mmol} / \mathrm{mol}$ (this study)).
[18] An additional replication test using parallel paths was conducted to investigate possible differences between sampling on opposing sides of the $\sim 0.5$-cm-thick coral slab (Figure 5). Coral $\mathrm{Sr} / \mathrm{Ca}$ determinations from parallel paths on opposing sides of 92-PAA1-A are not significantly different (Figure 5a), are reproducible within $2 \sigma$ of the analytical precision, and the $\operatorname{avg}_{\text {abs }}(0.032 \mathrm{mmol} / \mathrm{mol})$ is comparable to the parallel path test on 92-PAC1-A. However, coral $\mathrm{Sr} / \mathrm{Ca}$ determinations for parallel paths on opposing sides of 92-PAA1-B exhibit a significant divergence in coral $\mathrm{Sr} / \mathrm{Ca}$ (Figure 5b). The cycles from 19661968 agree within analytical precision; however, before 1966 , the two paths diverge and the difference $\left(\operatorname{avg}_{\mathrm{abs}}=\right.$ $0.093 \mathrm{mmol} / \mathrm{mol}$ ) between the paths increases beyond analytical error. Closer examination of the coral slab under magnification revealed the corallites on the original sam- 


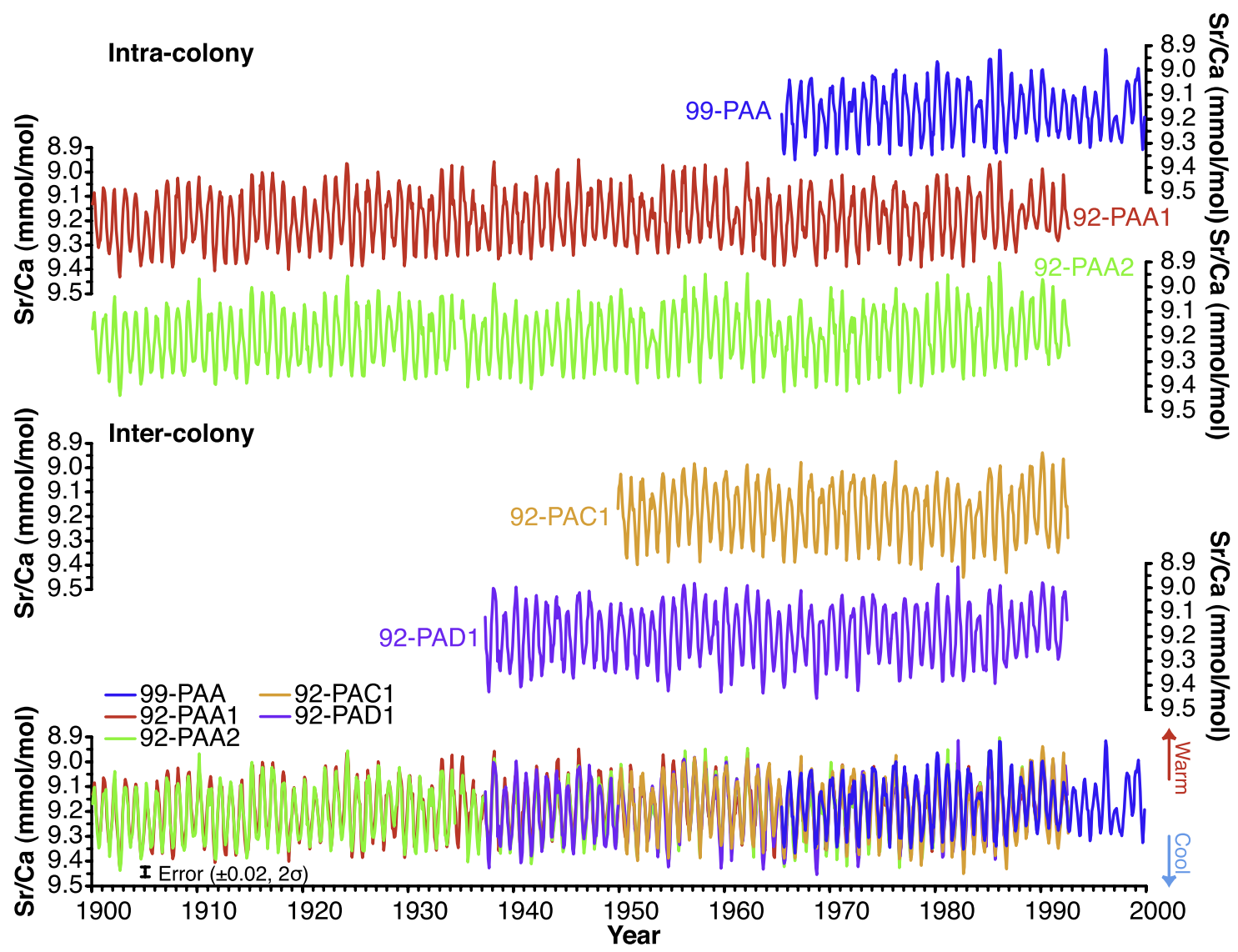

Figure 6. (top) Intracolony and (middle) intercolony monthly coral $\mathrm{Sr} / \mathrm{Ca}$ variations. Three cores (99PAA, 92-PAA1, and 92-PAA2) are from the same coral colony (PAA), and the other two (92-PAC1 and 92-PAD1) are colonies in close proximity to PAA. (bottom) Monthly coral $\mathrm{Sr} / \mathrm{Ca}$ records plotted together. Three records (92-PAC1, 92-PAD1, and 99-PAA) were originally sampled by Stephans et al. [2004] and 92-PAC1 and 92-PAD1 were extended in this study (Table 1). The means and standard deviations for the five coral $\mathrm{Sr} / \mathrm{Ca}$ are not significantly different, and $r \geq 0.92$ for the period 1900-1999. Note the high degree of reproducibility between coral $\mathrm{Sr} / \mathrm{Ca}$ time series.

pling side of the slab were not oriented parallel to the sampling path, a sampling orientation that has previously been identified as problematic [Alibert and McCulloch, 1997]. In this specific case, samples extracted from the suboptimal sampling pathway yielded lower $\mathrm{Sr} / \mathrm{Ca}$ values relative to the values produced from the other samples, which when converted to SST would produce elevated temperature values $\left(1^{\circ}-3^{\circ} \mathrm{C}\right)$. Additional comparison of $\delta^{18} \mathrm{O}, \delta^{13} \mathrm{C}$, and $\mathrm{Mg} / \mathrm{Ca}$ between the original sampling side and opposing side of 92-PAA1-B did not reveal an offset (Figure 5b). The coral $\mathrm{Sr} / \mathrm{Ca}$ records from 92-PAA2, 92-PAC1, and 92-PAD1 agree with the variations on the opposing side of 92-PAA1-B (Figure 6) and suboptimal data from original sampling side of 92-PAA1-B were not used further.

[19] The next spatial step assessed the reproducibility of monthly coral $\mathrm{Sr} / \mathrm{Ca}$ variations between synchronous cores from same coral colony (PAA; Figures 6 and 7). Two cores, 92-PAA1 and 92-PAA2, were compared for the twentieth century and the third core, 99-PAA [Stephans et al., 2004], was compared with 92-PAA1 and 92-PAA2 for the period 1965-1992. The means of the monthly intracolony coral
$\mathrm{Sr} / \mathrm{Ca}$ variations are not significantly different (Table 2 and Figure 6) and the coral $\mathrm{Sr} / \mathrm{Ca}$ variations are highly correlated $(r \geq 0.93, p<0.05, n=328$, for 1965-1992; $r=0.93, p<0.05, n=1112$, for 1900-1992; Table 3). The avg $_{\text {abs }}$ between coral $\mathrm{Sr} / \mathrm{Ca}$ determinations for PAA is similar to the parallel paths $(0.033 \pm 0.024 \mathrm{mmol} / \mathrm{mol}, 1 \sigma$, monthly; $0.021 \pm 0.016 \mathrm{mmol} / \mathrm{mol}, 1 \sigma$, annual average).

[20] The last spatial test assessed intercolony reproducibility of monthly coral $\mathrm{Sr} / \mathrm{Ca}$ variations. This study builds upon the previous study of Stephans et al. [2004] by extending the coral records 92-PAC1 to 1950 (an additional 13 a) and 92-PAD1 to 1937 (an additional 30 a) and comparing the monthly coral $\mathrm{Sr} / \mathrm{Ca}$ variations from 92-PAC1, 92-PAD1, and the three PAA coral records (Figures 6 and 8). The means and standards deviations of five coral $\mathrm{Sr} / \mathrm{Ca}$ records are not significantly different (Table 2), the monthly coral $\mathrm{Sr} / \mathrm{Ca}$ records are highly reproducible $(r \geq 0.91, p<0.05$; Table 3$)$, the overall avg $_{\text {abs }}$ is $0.035 \pm 0.026 \mathrm{mmol} / \mathrm{mol}(1 \sigma)$, and the standard error of the individual records with the monthly stack average record is $0.011 \mathrm{mmol} / \mathrm{mol}(n=5256)$. The monthly 


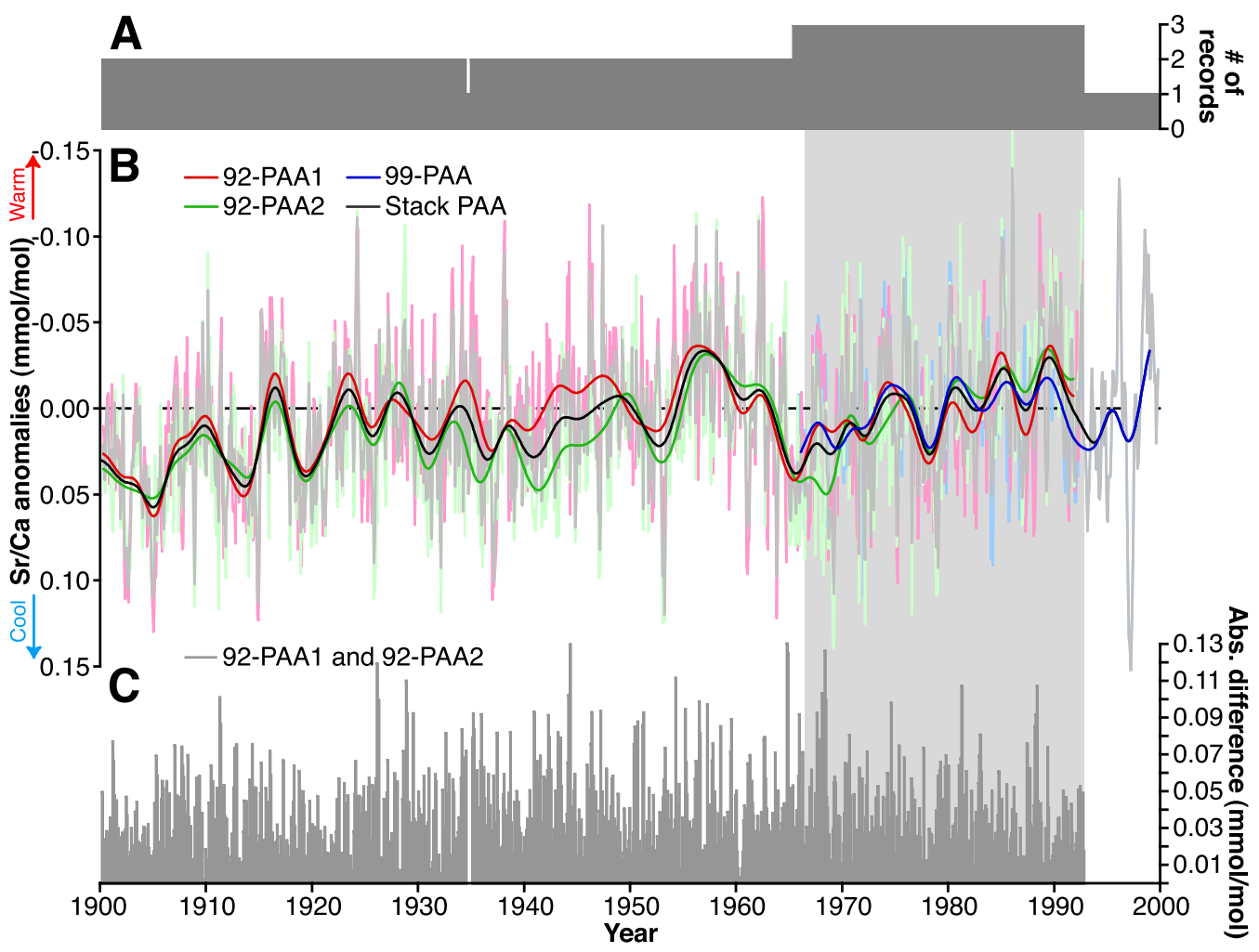

Figure 7. Intracolony coral $\mathrm{Sr} / \mathrm{Ca}$ reproducibility (99-PAA, 92-PAA1, and 92-PAA2). (a) Number of records reflecting core coverage. (b) Anomalies calculated as the difference between each monthly measurement and the average $\mathrm{Sr} / \mathrm{Ca}$ value for each month for the interval 1967-1992 (gray rectangle). The three intracolony records were averaged to create a stack PAA. Each monthly coral $\mathrm{Sr} / \mathrm{Ca}$ record was smoothed using a 48-month finite impulse response (FIR) filter. The coral $\mathrm{Sr} / \mathrm{Ca}$ anomalies are reproducible for the period $1900-1999(r=0.60$ to $0.70, p<0.05$; Table 3$)$, and the means are not significantly different. (c) Absolute value of the difference between 92-PAA1 and 92-PAA2. The avg $g_{a b s}$ is $0.031 \mathrm{mmol} / \mathrm{mol}$.

coral $\mathrm{Sr} / \mathrm{Ca}$ anomalies for each coral record was calculated by subtracting the respective monthly mean with respect to the period 1967-1992 (Figures 7 and 8). The average of the correlation coefficients between monthly coral $\mathrm{Sr} / \mathrm{Ca}$ anomalies is 0.57 for 1967-1992 and for 1900-1992 (Table 3). The stack coral $\mathrm{Sr} / \mathrm{Ca}$ record for Amédée Island is composed of the average of three intracolony coral records (99-PAA, 92-PAA, and 92-PAA2) to create the stack PAA colony record, which was then averaged with the intercolony records (92-PAC1 and 92-PAD1). The stack monthly coral $\mathrm{Sr} / \mathrm{Ca}$ variations and anomalies are signifi- cantly correlated with the individual monthly coral $\mathrm{Sr} / \mathrm{Ca}$ records (Table 3). The means and standards deviations of five annual average coral $\mathrm{Sr} / \mathrm{Ca}$ records are not significantly different, the annual average coral $\mathrm{Sr} / \mathrm{Ca}$ records are reproducible ( $r=0.56$ to $0.83, p<0.05)$, and the overall avg $g_{\text {abs }}$ is $0.021 \pm 0.017 \mathrm{mmol} / \mathrm{mol}(1 \sigma)$.

\subsection{Coral Geochemistry and SST}

[21] SST variations have been shown to drive variations in carbonate $\mathrm{Sr} / \mathrm{Ca}$ in coral skeletons [Weber, 1973; Smith et al., 1979; Beck et al., 1992]. The monthly coral $\mathrm{Sr} / \mathrm{Ca}$

Table 2. Monthly Coral Sr/Ca Determinations for $1900-1999^{\mathrm{a}}$

\begin{tabular}{|c|c|c|c|c|c|c|c|}
\hline & 99-PAA & 92-PAA1 & 92-PAA2 & Stack PAA $^{\mathrm{b}}$ & 92-PAC1 & 92-PAD1 & Stack Master $^{\mathrm{c}}$ \\
\hline Mean & 9.168 & 9.179 & 9.196 & 9.185 & 9.179 & 9.186 & 9.187 \\
\hline $\mathrm{SD}^{\mathrm{d}}$ & 0.097 & 0.101 & 0.102 & 0.099 & 0.110 & 0.109 & 0.101 \\
\hline Maximum & 9.361 & 9.400 & 9.430 & 9.407 & 9.448 & 9.452 & 9.407 \\
\hline Minimum & 8.914 & 8.912 & 8.900 & 8.914 & 8.935 & 8.912 & 8.914 \\
\hline$n^{\mathrm{e}}$ & 414 & 1112 & 1106 & 1198 & 511 & 661 & 1198 \\
\hline
\end{tabular}

${ }^{\mathrm{a}} \mathrm{Sr} / \mathrm{Ca}$ values are given in $\mathrm{mmol} / \mathrm{mol}$.

${ }^{\mathrm{b}}$ Stack PAA is the average of the three intracolony records (99-PAA, 92-PAA1, and 92-PAA2).

${ }^{\mathrm{c}}$ Stack master is the average of the three intercolony records (PAA, 92-PAC1, and 92-PAD1).

${ }^{\mathrm{d}} \mathrm{SD}$ is standard deviation.

'The number of observations for each series is listed; however, each series spans a different period: 1965-1999 for 99-PAA; 1900-1992 for 92-PAA1 and 92-PAA2; 1950 - 1992 for 92-PAC1; and 1937-1992 for 92-PAD1. 
Table 3. Correlation Between Monthly Coral $\mathrm{Sr} / \mathrm{Ca}$ Variations and $\mathrm{SST}^{\mathrm{a}}$

\begin{tabular}{|c|c|c|c|c|c|c|c|c|c|}
\hline & 99-PAA & 92-PAA1 & 92-PAA2 & Stack PAA & 92-PAC1 & 92-PAD1 & Stack Master & IRD SST & HadISST_AI \\
\hline \multicolumn{10}{|c|}{$1967-1992(n=302)$} \\
\hline 99-PAA & 1.00 & 0.94 & 0.94 & 0.98 & 0.92 & 0.92 & 0.96 & -0.92 & -0.92 \\
\hline 92-PAA1 & 0.69 & 1.00 & 0.93 & 0.98 & 0.92 & 0.93 & 0.96 & -0.92 & -0.92 \\
\hline 92-PAA2 & 0.64 & 0.65 & 1.00 & 0.98 & 0.91 & 0.92 & 0.96 & -0.90 & -0.91 \\
\hline Stack PAA ${ }^{b}$ & 0.88 & 0.89 & 0.88 & 1.00 & 0.94 & 0.94 & 0.98 & -0.94 & -0.94 \\
\hline 92-PAC1 & 0.50 & 0.57 & 0.48 & 0.59 & 1.00 & 0.93 & 0.98 & -0.95 & -0.94 \\
\hline 92-PAD1 & 0.52 & 0.60 & 0.53 & 0.62 & 0.53 & 1.00 & 0.98 & -0.93 & -0.94 \\
\hline Stack master ${ }^{\mathrm{C}}$ & 0.74 & 0.80 & 0.73 & 0.86 & 0.85 & 0.84 & 1.00 & -0.96 & -0.96 \\
\hline IRD SST & -0.51 & -0.50 & -0.37 & -0.52 & -0.63 & -0.47 & -0.64 & 1.00 & 0.96 \\
\hline HadISST_AI & -0.47 & -0.52 & -0.42 & -0.53 & -0.52 & -0.51 & -0.61 & -0.64 & 1.00 \\
\hline \multicolumn{10}{|c|}{ Twentieth Century (1900-1999) } \\
\hline 99-PAA & 1.00 & 0.94 & 0.93 & 0.98 & 0.92 & 0.92 & 0.96 & -0.92 & -0.91 \\
\hline 92-PAA1 & 0.70 & 1.00 & 0.93 & 0.98 & 0.92 & 0.93 & 0.97 & -0.92 & -0.93 \\
\hline 92-PAA2 & 0.64 & 0.60 & 1.00 & 0.98 & 0.92 & 0.92 & 0.97 & -0.90 & -0.93 \\
\hline Stack PAA ${ }^{b}$ & 0.90 & 0.88 & 0.88 & 1.00 & 0.94 & 0.95 & 0.99 & -0.92 & -0.94 \\
\hline 92-PAC1 & 0.51 & 0.53 & 0.53 & 0.59 & 1.00 & 0.94 & 0.98 & -0.95 & -0.95 \\
\hline 92-PAD1 & 0.53 & 0.55 & 0.54 & 0.62 & 0.55 & 1.00 & 0.98 & -0.93 & -0.95 \\
\hline Stack master ${ }^{\mathrm{c}}$ & 0.79 & 0.81 & 0.81 & 0.92 & 0.86 & 0.86 & 1.00 & -0.94 & -0.95 \\
\hline IRD SST & -0.57 & -0.49 & -0.36 & -0.56 & -0.62 & -0.47 & -0.59 & 1.00 & 0.94 \\
\hline HadISST AI & -0.50 & -0.49 & -0.45 & -0.55 & -0.51 & -0.52 & -0.56 & 0.60 & 1.00 \\
\hline$n^{\mathrm{d}}-$ & 414 & 1112 & 1106 & 1198 & 511 & 661 & 1198 & 394 & 1198 \\
\hline
\end{tabular}

${ }^{a}$ Correlations between monthly anomalies appear in italics. Anomalies are calculated as the difference between each monthly measurement and the average $\mathrm{Sr} / \mathrm{Ca}$ value for each month for the interval 1967-1992. All correlations are significant $(p<0.05)$.

${ }^{\mathrm{b}}$ Stack PAA is the average of the three intracolony records (99-PAA, 92-PAA1, and 92-PAA2).

${ }^{\mathrm{c}}$ Stack master is the average of the three intercolony records (PAA, 92-PAC1, and 92-PAD1).

${ }^{\mathrm{d}}$ The number of observations for each series is listed; however, each series spans a different period: 1965-1999 for 99-PAA; 1900-1992 for 92-PAA1 and 92-PAA2; 1950-1992 for 92-PAC1; and 1937-1992 for 92-PAD1.

variations for this study are significantly correlated with monthly IRD SST and HadISST_AI for the period common to all records $(r \geq-0.90,-0.91$, respectively, $p<0.05, n=$ $304 ; 1967-1992)$ and correlations do not vary greatly for the extended twentieth century records (Table 3). The correlation between the stack average coral $\mathrm{Sr} / \mathrm{Ca}$ and the HadISST_AI increased (up to $4 \%$ for monthly, 8 to $24 \%$ for anomalies) for the twentieth century by averaging the five monthly coral $\mathrm{Sr} / \mathrm{Ca}$ determinations thus increasing the signal-to-noise ratio (Table 3 ). The monthly stack coral $\mathrm{Sr} / \mathrm{Ca}$ anomalies are significantly correlated with IRD SST anomalies and HadISST_AI anomalies for the period $1967-$ $1992(r=-0.64,-0.6 \overline{1}$, respectively; $p<0.05, n=302$; Table 3 ) and the HadISST_AI anomalies decreased by $\sim 8 \%$ for the stack coral $\mathrm{Sr} / \overline{\mathrm{Ca}}$ record extended to the year $1900(r=-0.56, p<0.05, n=1198$; Table 3$)$. The correlation between the stack coral $\mathrm{Sr} / \mathrm{Ca}$ and SST anomalies is slightly less than the correlation between IRD SST and HadISST_AI $(r=0.64, p<0.05, n=302$; Table 3$)$. The annual average of the stack coral $\mathrm{Sr} / \mathrm{Ca}$ is significantly correlated with annual average IRD SST and HadISST_AI for the twentieth century $(r=-0.56,-0.72$, respectively; $n=$ 33 , 99, respectively; $p<0.05$ ); however, the correlation between some of the individual annual average coral $\mathrm{Sr} / \mathrm{Ca}$ records and IRD SST are not significant, possibly attributed to the small number of observations $(n<25)$.

\section{Discussion}

[22] This study expands upon previous studies of coral geochemical variations at Amédée Island, New Caledonia by (1) expanding the sample resolution test to coral $\mathrm{Sr} / \mathrm{Ca}$ and to higher-resolution sampling (section 5.1), (2) assess- ing the chronology error (section 5.2), (3) extending the test of reproducibility in coral $\mathrm{Sr} / \mathrm{Ca}$ to span the entire twentieth century (section 5.3), (4) assessing the stack coral $\mathrm{Sr} / \mathrm{Ca}$ record using dendrochronology methods (section 5.4), (5) comparing coral $\mathrm{Sr} / \mathrm{Ca}$ variations with local SST (section 5.5), and (6) verifying the coral $\mathrm{Sr} / \mathrm{Ca}-\mathrm{SST}$ calibration with gridded SST data products for the twentieth century (section 5.6).

\subsection{Sampling Resolution}

[23] Examination of the coral $\mathrm{Sr} / \mathrm{Ca}$ and $\delta^{18} \mathrm{O}$ variations sampled at different resolutions reveals that there is minimal loss in the skill of capturing the mean of the annual cycle or the mean coral $\mathrm{Sr} / \mathrm{Ca}$ and $\delta^{18} \mathrm{O}$ for the interval tested. Corals do not grow at a continuous rate and growth can vary with the seasons. The monthly resolved $\mathrm{Sr} / \mathrm{Ca}$ and $\delta^{18} \mathrm{O}$ were able to capture the winter minima and summer maxima present in the fortnightly resolved records (Figures 3a and $3 \mathrm{~b}$ ). The seasonal $\delta^{18} \mathrm{O}$ record was able capture summer maxima; however, the winter minima were not captured in some years (Figure 3a). The annual cycle amplitude increased with finer sampling resolutions; however, the increase was not linear, but leveled off with increasing resolution; a similar tapering was observed with comparable filtering of the daily IRD SST (Figures 3d and 3e). The difference between summer and winter amplitudes is not significant for monthly and fortnightly $\mathrm{Sr} / \mathrm{Ca}$; however, the seasonal and monthly $\delta^{18} \mathrm{O}$ summer and winter amplitudes do differ. The multiple sampling resolution comparison assumes that the difference between the parallel sampling paths utilized for each resolution is equal to or less than analytical precision. This assumption was tested for a 20-a interval on 92-PAC1 (Figure 4), which demonstrated that the coral $\mathrm{Sr} / \mathrm{Ca}$ vari- 


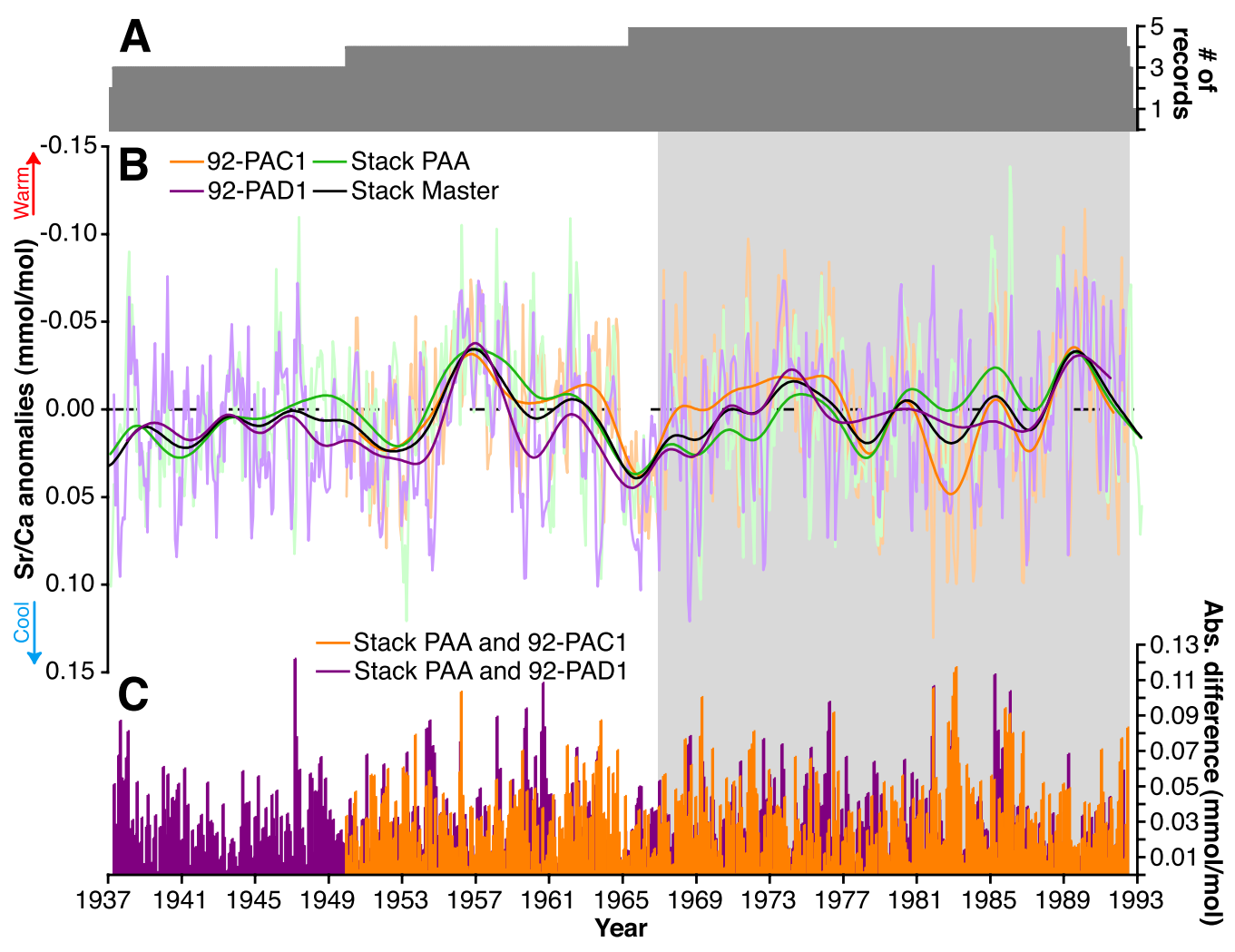

Figure 8. Intercolony coral $\mathrm{Sr} / \mathrm{Ca}$ reproducibility (stack PAA, 92-PAC1, and 92-PAD1). (a) Number of records reflecting core coverage. (b) Anomalies calculated as the difference between each monthly measurement and the average $\mathrm{Sr} / \mathrm{Ca}$ value for each month for the interval 1967-1992 (gray rectangle). The three intercolony records were averaged to create a stack master record for the Amédée Island. Each monthly coral $\mathrm{Sr} / \mathrm{Ca}$ record was smoothed using a 48-month FIR filter. The coral $\mathrm{Sr} / \mathrm{Ca}$ anomalies are reproducible for the period 1900-1999 ( $r=0.51$ to $0.70, p<0.05$; Table 3$)$, and the means are not significantly different. (c) Absolute value of the difference between colonies. The overall avg $\mathrm{abs}_{\mathrm{as}}$ is $0.035 \mathrm{mmol} / \mathrm{mol}$.

ability between adjacent paths was within analytical precision.

[24] Recent investigations of micron-scale variations in coral skeletal $\mathrm{Sr} / \mathrm{Ca}$ concluded that micron-scale frequency variations in coral $\mathrm{Sr} / \mathrm{Ca}$ are not related to SST variations [Meibom et al., 2003; Allison and Finch, 2004; Cohen and Sohn, 2004; Sinclair, 2005]. Meibom et al. [2003] observed approximately monthly oscillations in coral $\mathrm{Sr} / \mathrm{Ca}$ sampled at $30 \mu \mathrm{m}$ (approximately daily), which they attributed to metabolic variability related to the lunar cycle. Cohen and Sohn [2004] attributed coral $\mathrm{Sr} / \mathrm{Ca}$ variations sampled in discrete $20 \mu \mathrm{m}$ spots (approximately daily) to tidal forcing. Allison and Finch [2004] examined differences in coral $\mathrm{Sr} / \mathrm{Ca}$ between centers of calcification (COCs), which are deposited at night, and fasciculi, which are deposited during the day, in fast and slow growing Porites lobata corals from Hawaii. Allison and Finch [2004] observed significantly higher coral $\mathrm{Sr} / \mathrm{Ca}$ values in the COCs, no significant difference in coral $\mathrm{Sr} / \mathrm{Ca}$ between the fast and slow growing corals, and both the fasciculi and COCs exhibit large $\mathrm{Sr} / \mathrm{Ca}$ heterogeneity $(\sim 1 \mathrm{mmol} / \mathrm{mol})$ not related to temperature, which they attribute to variations in calcification rates. Sinclair [2005] microsampled Porites corals from the Great
Barrier Reef, Australia and reported large-magnitude, submonthly coral $\mathrm{Sr} / \mathrm{Ca}$ variability, which would equate to $\sim 20^{\circ} \mathrm{C}$. Unlike Meibom et al. [2003] and Cohen and Sohn [2004], Sinclair [2005] did not observe concentrations of variance at common periodicities and noted different variations between corals. Previous coral-based climate reconstructions contrast with micron-scale investigations, which use micron-scale sampling to recover $\sim 1 \mu \mathrm{m}^{2}$ area from within a single corallite, whereas typical coral-based climate reconstructions sample an $\sim 1 \mathrm{~mm}^{2}$ area which may contain multiple corallites depending on the species. This study sampled at $0.70 \mathrm{~mm}$ (approximately monthly) intervals using a $1.4 \mathrm{~mm}$ drill bit and each sample area contains $\sim 1.47 \mathrm{~mm}^{2}$ of coral skeletal material from multiple Porites lutea corallites ( $\sim 2$ to 4 corallites). Nothdurft and Webb [2007] studied the microstructure and spatial variability of skeletal growth in four coral genera including Porites and they recommend caution is needed when microsampling that "even a slight lateral divergence may invalidate the time series" [see Nothdurft and Webb, 2007, Figure 17].

[25] The continuous sampling method used by Quinn et al. [1996] addresses the issue of aliasing high frequencies in coral-based climate reconstructions and this method is 
utilized in this study and many others [e.g., Alibert and McCulloch, 1997; Quinn et al., 1998; Linsley et al., 2000; Hendy et al., 2002; Quinn and Sampson, 2002; Stephans et al., 2004; Linsley et al., 2006]. The continuous sampling method involves drilling a channel in the coral along the maximum growth axis and removing a homogenized coral powder sample for some interval length, which in mathematical terms equates to a moving average or smoothing function. The continuous sampling method is quite different from sampling the coral skeletal material in discrete points such that minimal information along the sampling path is lost as the signal is averaged over the sampling interval. If frequencies higher than the sampling interval are present in the coral skeletal material, the continuous sampling method averages these fluctuations producing a smoothed record. The cost of smoothing or filtering data is a loss of variance. This is illustrated in the filtered IRD daily SST record and multiple sampling resolution experiment (Figure 3e). As the sampling interval doubled from fortnightly to monthly (30 samples/cm to 15 samples/cm), the variance decreased in each geochemical record as expected (Figure 3). The percent reduction in standard deviation from fortnightly to monthly for IRD SST record $(1.7 \% \mathrm{SST})$ is less than the coral records $\left(6.9 \% \mathrm{Sr} / \mathrm{Ca}, 3.9 \% \delta^{18} \mathrm{O}\right.$, and $\left.5.0 \% \delta^{13} \mathrm{C}\right)$. The IRD SST was discretely sampled once per day at 7:00 A.M. and is not a fully continuous daily record. Therefore the IRD SST record lacks the high-frequency power $(<1$ day $)$ that contributes to the overall variance in a continuous sample. The results of the sampling-resolution test reveal a minimal loss in variance for twice the sampling interval and no significant change in the mean value of coral $\mathrm{Sr} / \mathrm{Ca}, \delta^{18} \mathrm{O}$, and $\delta^{13} \mathrm{C}$. Allison and Finch [2004] performed a similar test with their micron-scale investigation results and noted a reduction in variance as smoothing intervals increased and that correlation with temperature increased as smoothing reached monthly and bimonthly intervals. The results from Allison and Finch [2004] and from this study support the conclusion reached by Quinn et al. [1996] that lower sampling resolutions (seasonally to monthly) in coral $\mathrm{Sr} / \mathrm{Ca}$ and $\delta^{18} \mathrm{O}$ captures an average annual temperature signal; however, this is true for the continuous sampling method and discrete sampling may produce erroneous results if frequencies higher than the Nyquist frequency are present.

\subsection{Chronology Error Assessment}

[26] A hallmark of tree ring reconstructions is the ability to precisely date the annual rings by cross dating many trees; therefore there are some concerns for climate reconstructions using a single, unreplicated coral record. Investigations using a single coral core typically have estimated chronology errors (1-2 a/century) when robust chronology error assessment is not possible. This study was able to estimate chronology error for the previous Amédée studies using the cross-dated master chronology. The chronology errors resulted in a net 2-a discrepancy at 1900 A.D. for the single core record described by Quinn et al. [1998] and a net 2-a discrepancy for the four-core, 25-a-long record by Stephans et al. [2004]. The 100-a-long, five core crossdated master chronology validates the estimated chronology error of $2 \mathrm{a} /$ century for both a single coral record spanning one century and multiple coral records over a quarter century. This chronology error assessment was conducted for only one century and chronology errors for longer coral records may be different.

\subsection{Replication of Coral $\mathrm{Sr} / \mathrm{Ca}$ Variations}

[27] High reproducibility of coral $\mathrm{Sr} / \mathrm{Ca}$ variations through the twentieth century was determined for intracolony and intercolony cores from coral heads that live in close proximity within the same reef. The overall avg abs $_{3}$ between coeval monthly $\mathrm{Sr} / \mathrm{Ca}$ determinations between any two coeval coral $\mathrm{Sr} / \mathrm{Ca}$ time series, whether parallel paths, intracolony, or intercolony, is $<2 \sigma$ of the magnitude of analytical precision, which corresponds to an average offset between any two cores of $0.65^{\circ} \mathrm{C}$ for any single month. The avg $_{\text {abs }}$ between the coral $\mathrm{Sr} / \mathrm{Ca}$ records may be due to differences in sampling resolution and sampling path. The effect of small differences in sampling resolution (12 to 16 samples/cm; Table 1) is judged to be within the variability observed at this location. The parallel path test demonstrated that the effect of sampling parallel to the maximum growth axis $(<0.5 \mathrm{~cm})$ is judged to be within the analytical precision of this study. An artificial source of offset between cores was introduced in the conversion from depth to time domain because of inadequate intra-annual alignment of coral records to the SST record (error $= \pm 1$ to 2 months) and every effort was made to remove any large offsets due to conversion from depth domain to time domain. The avg $_{\text {abs }}$ was reduced by $26 \%$ to $0.026 \mathrm{mmol} / \mathrm{mol}$ after applying a 5-month finite impulse response (FIR) filter [Bloomfield, 2000] to minimize the effects of intra-annual chronology errors. The reproducibility of the coral $\mathrm{Sr} / \mathrm{Ca}$ signal for the twentieth century agrees with the previous shorter interval study by Stephans et al. [2004] and the results (Table 3 and Figures 6, 7, and 8) demonstrate that monthly resolved coral $\mathrm{Sr} / \mathrm{Ca}$ variations, both intracolony and intercolony, are recording the same signal and that environmental variations outweigh biological variations in the monthly average coral $\mathrm{Sr} / \mathrm{Ca}$ signal.

\subsection{Comparison With Dendrochronology Methods}

[28] This study has demonstrated that multiple monthly coral $\mathrm{Sr} / \mathrm{Ca}$ records from New Caledonia share a common environmental signal, but how do these results compare with statistical methodologies utilized in climate studies based on tree rings? Dendrochronologists employ correlation analysis to assess the common variability between individual chronologies and the master chronology [Fritts, 1976]. A similar correlation analysis with the Amédée Island monthly coral $\mathrm{Sr} / \mathrm{Ca}$ records was conducted and found high correlation coefficients $(r=0.96$ to $0.98, p<$ 0.05; Table 3) between the coral records and the master coral $\mathrm{Sr} / \mathrm{Ca}$ record for the periods 1967-1999 and the twentieth century. Tree ring chronologies are constructed using annual growth rings, and thus have annual resolution. In order to compare coral records on par with tree ring records, the climatological annual average (April to March) was calculated for each coral $\mathrm{Sr} / \mathrm{Ca}$ record and correlation analysis was performed $(r=0.81$ to $0.89, p<0.05)$. The expressed population signal (EPS) is the statistical quality of the mean chronology gauged against the hypothetically 


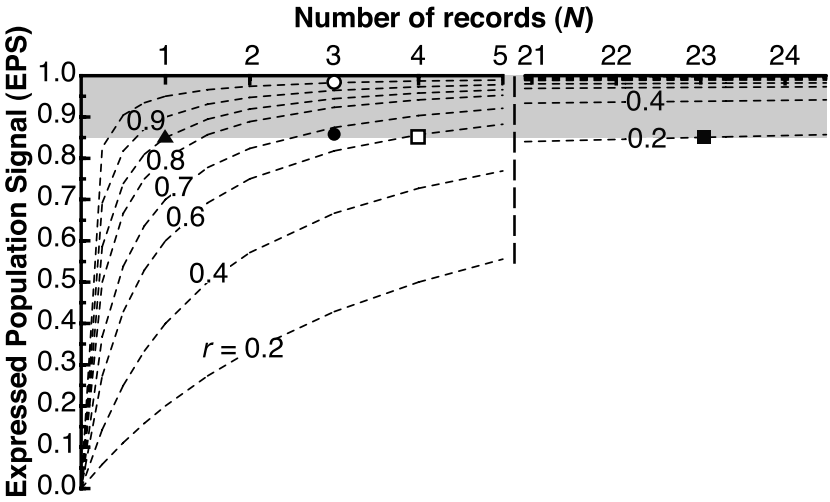

Figure 9. The expressed population signal (EPS). The EPS statistic from dendroclimatology [Wigley et al., 1984] is used to determine the number of records $(N)$ required for a mean interseries correlation coefficient $(\bar{r})$ to produce an acceptable signal-to-noise ratio, which was arbitrarily set as $\geq 0.85$ (gray box) by Wigley et al. [1984]. Trees in arid regions $(\bar{r}=0.6$, open square $)$ have a higher environmental sensitivity, and fewer records are needed $(N$ =4) than deciduous trees $(\bar{r}=0.2, N=23$, solid square $)$ [Cook and Kairiukstis, 1990]. The EPS for this study $(N=$ $3, \bar{r}=0.94$, EPS $=0.98$, for monthly coral $\mathrm{Sr} / \mathrm{Ca}$, open circle; $\mathrm{EPS}=0.86$ for annual average coral $\mathrm{Sr} / \mathrm{Ca}$, solid circle) is greater than the tree ring EPS threshold value. A single well-dated monthly coral $\mathrm{Sr} / \mathrm{Ca}$ record with a correlation to SST $>0.85$ (triangle) could be interpreted as an acceptable signal-to-noise ratio $(\bar{r}=0.85$, EPS $=0.85)$. Graph is adapted from Briffa [1995].

noise-free chronology where $N$ is the number of records (trees or coral colonies) and $(\bar{r})$ is the mean interseries correlation coefficient between all trees in the chronology [Wigley et al., 1984]:

$$
\mathrm{EPS}=\frac{N(\bar{r})}{N(\bar{r})+(1-\bar{r})}
$$

Dendrochronologists utilized EPS to determine the number of replicates needed to increase the signal-to-noise ratio to an acceptable level, which was arbitrarily set to $\geq 0.85$ by Wigley et al. [1984]; the closer the EPS value to one, the stronger the signal [Wigley et al., 1984; Briffa, 1995]. For example (Figure 9), trees in arid regions $(\bar{r}=0.6)$ have a higher environmental sensitivity and fewer records are needed $(N=4)$ than deciduous trees $(\bar{r}=0.2, N=23)$ [Cook and Kairiukstis, 1990]. The EPS for this study $(N=3$ coral colonies, $\bar{r}=0.94$ ) is 0.98 for monthly coral $\mathrm{Sr} / \mathrm{Ca}$ and 0.86 for annual average coral $\mathrm{Sr} / \mathrm{Ca}(\bar{r}=0.66$, Figure 9); these EPS values indicate that the stack coral $\mathrm{Sr} / \mathrm{Ca}$ chronology is acceptable using criteria from tree ring studies. The coral $\mathrm{Sr} / \mathrm{Ca}$ records from this study were tested using statistical methods from dendrochronology that demonstrate the coral $\mathrm{Sr} / \mathrm{Ca}$ variations are highly reproducible and should be evaluated as equivalent to highly sensitive tree ring records.

\subsection{Coral Sr/Ca Relationship With SST}

[29] A strong relationship between coral $\delta^{18} \mathrm{O}$ and $\mathrm{Sr} / \mathrm{Ca}$ with SST has been previously reported for corals from Amédée Island, New Caledonia [Beck et al., 1992; Quinn et al., 1996, 1998; Corrège et al., 2000; Quinn and Sampson, 2002; Stephans et al., 2004] and this study's expanded New Caledonia coral $\mathrm{Sr} / \mathrm{Ca}$ record exhibits the same strong relationship with SST (Figures 10 and 11). The correlations between monthly coral $\mathrm{Sr} / \mathrm{Ca}$ and $\mathrm{SST}$ are similar to the values reported by Quinn and Sampson [2002] and slightly improved from correlations reported by Stephans et al. [2004] because of adjustments made to the chronology of 92-PAD1. Stack averaging the coral $\mathrm{Sr} / \mathrm{Ca}$ records into a master coral $\mathrm{Sr} / \mathrm{Ca}$ record further improved the correlation between SST and coral $\mathrm{Sr} / \mathrm{Ca}$ (Table 3) by increasing the signal-to-noise ratio. The extension of the Amédée Island coral $\mathrm{Sr} / \mathrm{Ca}$ record demonstrates that the monthly stack coral $\mathrm{Sr} / \mathrm{Ca}$ signal remains strongly correlated with SST in the twentieth century and that the correlation remains significant for both monthly anomalies (Table 3 ) and annual averages $(r=-0.72, n=99, p<0.05)$. A comparison with other monthly gridded SST data products (e.g., ERSST [Smith and Reynolds, 2004], COADS (R. J. Slutz et al., Comprehensive Ocean-Atmosphere Data Set; Release 1, Climate Research Program, Boulder, Colorado, 1985, hereinafter referred to as Slutz et al., Comprehensive Ocean-Atmosphere Data Set; Release 1, 1985), and GISST [Parker et al., 1995]) shows similar results for grid areas centered on Amédée Island.

[30] The MLE is a generalized linear regression solution that does not assume the variables are error-free and allows the variance in the regressors to vary. The MLE transfer function for the monthly stack coral $\mathrm{Sr} / \mathrm{Ca}$ determinations with IRD SST was estimated for the period 1967-1999 $(R=$ $0.94, p<0.05, n=392)$ with an error of regression $\left(\sigma_{\text {reg }}\right)$ of $1.29^{\circ} \mathrm{C}($ dof $=105)$.

$$
\begin{aligned}
\operatorname{SST}\left({ }^{\circ} \mathrm{C}\right)= & 193.59( \pm 1.70,2 \sigma) \\
& -\mathrm{Sr} / \mathrm{Ca}(18.524( \pm 0.185,2 \sigma))
\end{aligned}
$$

$$
\begin{aligned}
\mathrm{Sr} / \mathrm{Ca}(\mathrm{mmol} / \mathrm{mol})= & 10.451( \pm 0.013,2 \sigma) \\
& -\operatorname{SST}(0.054( \pm 0.001,2 \sigma))
\end{aligned}
$$

The MLE regression used (1) a coral $\mathrm{Sr} / \mathrm{Ca}$ error matrix $\left(\sigma_{\mathrm{Sr} / \mathrm{Ca}}\right)$ based on the error estimated for each month by the deviation between the individual records and the stack record and the number of records in the stack average for that month and (2) the IRD SST error matrix $\left(\sigma_{\mathbf{S S T}}\right)$ based on type of measurement and number of observations. The monthly stack coral $\mathrm{Sr} / \mathrm{Ca}$ determinations and the corresponding monthly IRD SST with error bars are plotted in Figure 10c. The stack coral $\mathrm{Sr} / \mathrm{Ca}$ determinations with only one observation have larger error bars and all the observations outside the main data cluster are single observations.

[31] Solow and Huppert [2004] discussed the potential for bias in ordinary least squares (OLS) linear regression when 


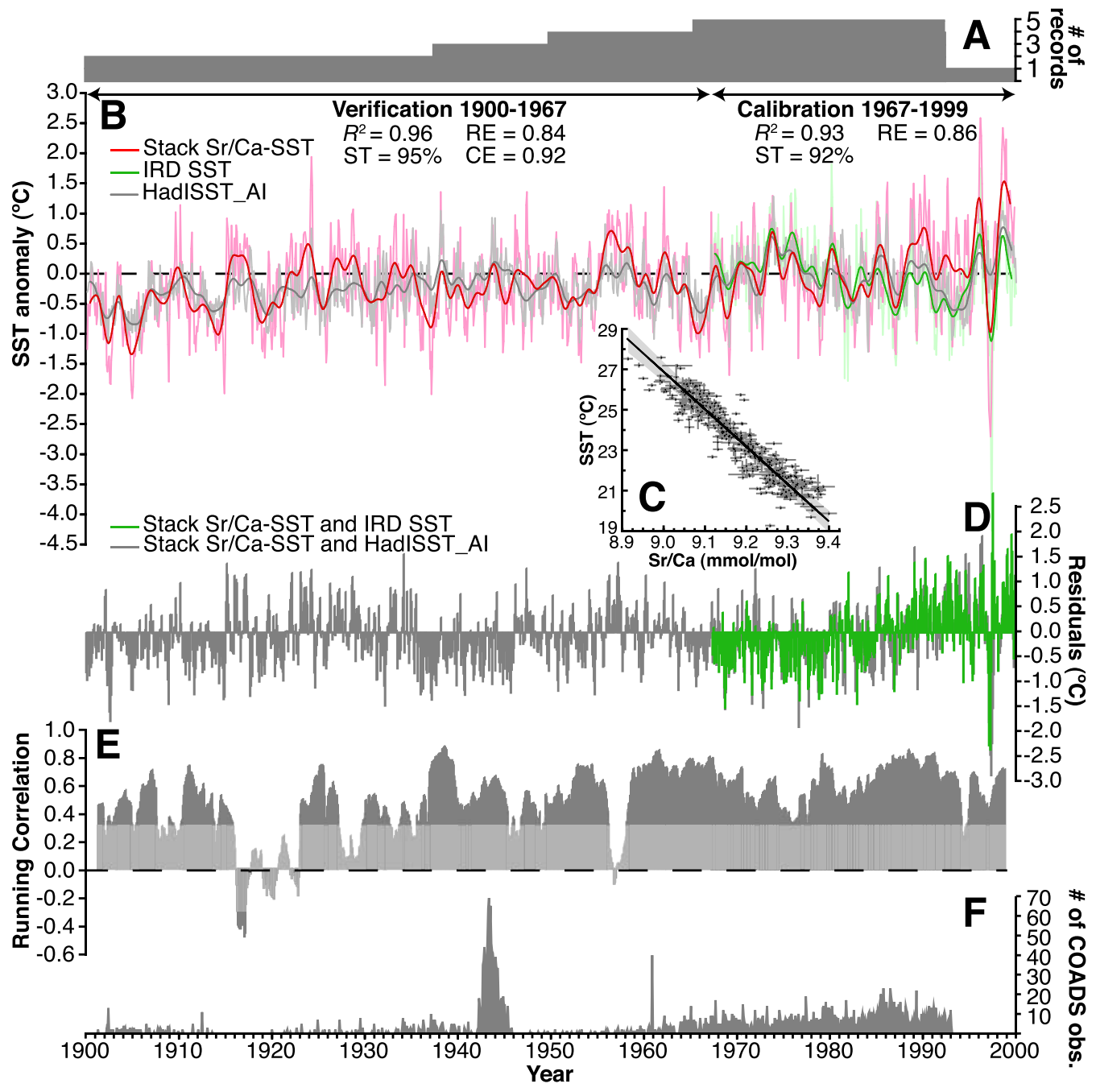

Figure 10. Calibration and verification of the coral $\mathrm{Sr} / \mathrm{Ca}-\mathrm{SST}$ transfer function. The coral $\mathrm{Sr} / \mathrm{Ca}$ was calibrated against IRD SST (1967-1999) and verified against HadISST_AI (1900-1967). (a) Number of records included in the stack coral $\mathrm{Sr} / \mathrm{Ca}$ record. (b) Monthly stack coral $\mathrm{Sr} / \mathrm{Ca}-\mathrm{SST}$, IRD SST, and HadISST_AI anomalies calculated as the difference between each monthly measurement and the average coral $\mathrm{Sr} / \overline{\mathrm{C}} \mathrm{a}-\mathrm{SST}$ value for each month for the interval 1967-1992. Monthly records were smoothed using a 24-month FIR filter. (c) Transfer function determined using MLE ( $R=0.94, p<0.05$, and $n=$ 392). Observations are reported with error bars for both coral $\mathrm{Sr} / \mathrm{Ca}$ and SST, and the gray region is the confidence band for the MLE regression. (d) Residuals of predicted coral $\mathrm{Sr} / \mathrm{Ca}-\mathrm{SST}$ minus the observed SST. (e) Running correlation (31-month) between coral Sr/Ca-SST and HadISST_AI. Shaded values are insignificant $(p<0.05)$. (f) Number of observations from the COADS SST database [Slutz et al., 1985] that correspond to HadISST_AI [Rayner et al., 2003].

SST is used as the independent variable and SST is assumed to be error-free. OLS and reduced major axis (RMA) are special cases of the general least squares method of MLE [York and Evensen, 2004] and OLS regression assumes the independent variable $(x)$ is perfectly known while RMA and MLE includes error in the independent variable. In order to compare regression methods, the transfer function was calculated with the independent variable $(x)$ as both SST and coral $\mathrm{Sr} / \mathrm{Ca}$. The MLE regression produces identical results unlike the OLS solutions thus negating the need to set SST as the independent variable. This study was fortunate in having a daily in situ SST record in close proximity to the coral colonies in order to assess the error in the SST measurement in detail. The monthly IRD SST error was estimated using the daily SST measurements and instrumental precision $\left(\sigma_{\text {precision }}= \pm 0.2^{\circ} \mathrm{C}\right)$. A histogram of the daily bucket measurements revealed $\sim 30 \%$ of the readings were whole numbers $(10 \%$ are expected to be whole numbers), which were assumed to be recording errors where readings were rounded to a whole number $\left(\sigma_{\text {rounded }}=\right.$ 


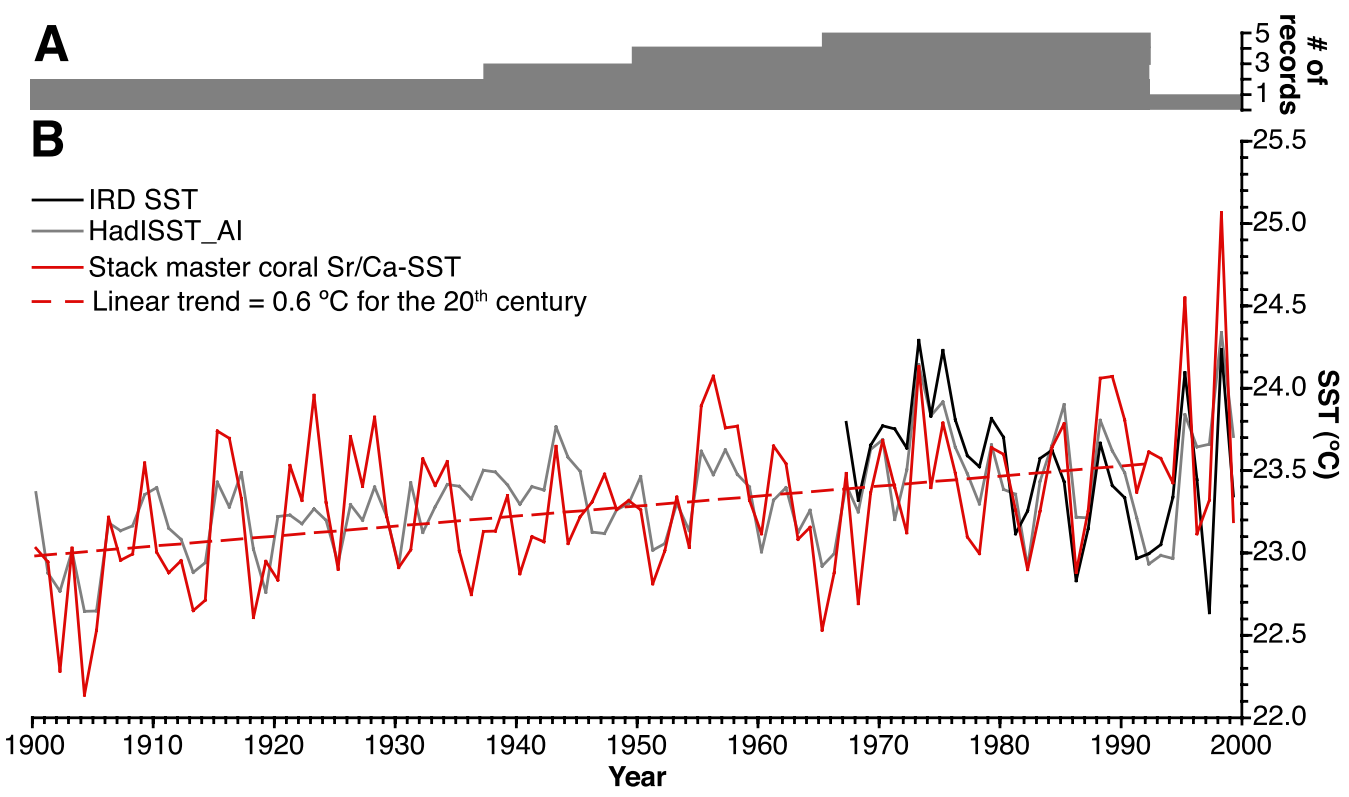

Figure 11. Annual average variations of the stack master coral $\mathrm{Sr} / \mathrm{Ca}-\mathrm{SST}$. (a) Number of coral $\mathrm{Sr} / \mathrm{Ca}$ records included in the stack coral $\mathrm{Sr} / \mathrm{Ca}$ record. (b) Annual average of stack coral Sr/Ca-SST compared with IRD SST and adjHadISST_AI $(r=0.72, p<0.05$, and $n=99)$. Annual averages were calculated over a climatological year (April to March). An $\sim 0.6^{\circ} \mathrm{C}$ warming trend is observed in the annual average coral $\mathrm{Sr} / \mathrm{Ca}-\mathrm{SST}$ for the period $1900-1992\left(\mathrm{Sr} / \mathrm{Ca}-\mathrm{SST}\left({ }^{\circ} \mathrm{C}\right)=0.006( \pm 0.003,2 \sigma)\right.$ year $+10.96( \pm 5.51$, $2 \sigma)$ ).

$\left.\pm 0.5^{\circ} \mathrm{C}\right)$. The daily measurement error for the period $1967-$ 1999 was increased to $\pm 0.26^{\circ} \mathrm{C}$ to account for possibility of recording errors $\left(80 \% \sigma_{\text {precision }}+20 \% \sigma_{\text {rounded }}= \pm 0.26^{\circ} \mathrm{C}\right)$. Examination of the daily bucket SST record found a period of approximately 1 a where all SST readings were rounded to a whole number and error was increased to $\sigma_{\text {rounded }}$. The daily IRD SST readings were mostly taken at 7:00 A.M. local time; however, the recording time did vary over the 33-a record and could possibly introduce a bias (see section 2). Delcroix and Lenormand [1997] adjusted the daily IRD SST observations to 7:00 A.M. based on a mean diurnal cycle to reduce recording time bias. After adjusting the daily SST to 7:00 A.M., the monthly average SST and the monthly average error was calculated using the standard error of a mean. The monthly IRD SST record contains months where no measurements were made and the corresponding SST from the adjusted HadISST_AI record was inserted to complete the IRD SST record. Rayner et al. [2003] reports the monthly HadISST1.1 error for a $2^{\circ}$ grid box decreased from 0.6 to $0.3^{\circ} \mathrm{C}$ for the period $1960-1995$ and the corresponding error was used for the adjusted HadISST_AI values. The SST error matrix was used to calculate $\mathrm{MLE}$ transfer function and the mean of the SST measurement errors $\left(\sigma_{\mathbf{S S T}}\right)$ is $0.10 \pm 0.13^{\circ} \mathrm{C}(1 \sigma)$.

[32] The Solow and Huppert [2004] bias correction for OLS can be evaluated using the error estimate for the monthly IRD SST and the MLE solution. If the Solow and Huppert [2004] SST bias $\left(\sigma_{\eta}^{2}\right)$ introduced by OLS regression was estimated as $0.14^{\circ} \mathrm{C}$, the bias correction would produce the same results as the MLE solution assuming the IRD SST is the best estimate of the true monthly SST. The $\sigma_{\eta}^{2}$ needed to correct the OLS transfer function is an order of magnitude greater than the mean of the IRD SST measurement variance $\left(\sigma_{\mathrm{SST}}^{2}=0.03 \pm 0.08\right.$, $1 \sigma$ ). Without SST measurement error information, applying the Solow and Huppert [2004] bias correction is difficult and is reduced to a best guess. Stephans et al. [2004] used the same SST record and some of the same coral records as this study; however, they applied the Solow and Huppert [2004] bias correction and their transfer function is significantly different from this study's MLE transfer function. A straightforward solution to the OLS bias problem discussed by Solow and Huppert [2004] is using a regression method such as MLE, which incorporates the error in both the dependent and independent variable.

\subsection{Calibration and Verification}

[33] A necessary step in the calibration of a climate proxy is the verification of the calibration against an independent data set for both the calibration interval (in this case, 19671999) and verification interval (in this case, 1900-1967). Previous Amédée Island studies [Quinn and Sampson, 2002; Stephans et al., 2004] calibrated coral Sr/Ca and $\delta^{18} \mathrm{O}$ with IRD SST which verified with the independent $1^{\circ}$ gridded SST (GISST2 [Parker et al., 1995]) for the calibration interval (1967-1992) and this study supports their findings (Figure 10). Crowley et al. [1999] tested the seasonal coral $\delta^{18} \mathrm{O}-\mathrm{SST}$ calibration $(1951-1991)$ by conducting a verification test for the period 1899-1950 which did not verify with the independent SST; however, an additional verification test using coral $\mathrm{Sr} / \mathrm{Ca}-\mathrm{SST}$ for the period 1898-1910 did verify with the independent SST. These 
results suggest that the coral $\delta^{18} \mathrm{O}$ outside the calibration interval has another forcing function such as salinity.

[34] This study takes a closer examination of the coral $\mathrm{Sr} / \mathrm{Ca}-\mathrm{SST}$ calibration by verifying the SST reconstruction over a century against the independent data set HadISST_AI and adjHadISST_AI. This study adopted of verification statistics from dendroclimatology to quantify the level of verification [Fritts, 1976; Fritts et al., 1979; Cook and Kairiukstis, 1990]. The statistics used in this study include correlation coefficient, sign test (ST), reduction of error (RE), and coefficient of efficiency (CE) [see Briffa et al., 1988; Cook and Kairiukstis, 1990] and results are summarized in Figure 10. The verification statistics show the calibration is robust for both the calibration interval (1967-1999) and the verification interval (1900-1967). The residuals between stack $\mathrm{Sr} / \mathrm{Ca}-\mathrm{SST}$ and IRD SST for the calibration interval exhibit a dominance of positive residuals from 1985-1999 and a dominance of negative residuals from 1967-1985 (Figure 10d). This pattern is not present in the residuals between stack $\mathrm{Sr} / \mathrm{Ca}-\mathrm{SST}$ and HadISST_AI and may be attributed to a negative trend in the IRD SST (Figure 10b) that is not present in either the coral Sr/Ca, HadISST_AI, other gridded SST data, SST from Uitoé, New Caled̄onia [Ourbak et al., 2006], or local air temperature records for this time interval. The negative trend in IRD SST is a source of residual error due to regression fitting mostly high frequencies rather than low frequencies; however, we do not believe the negative trend in IRD SST is real but may be the result of measurement bias (see discussion in section 2 and 5.5). Overall, the verification demonstrates the transfer function for the coral $\mathrm{Sr} / \mathrm{Ca}-\mathrm{SST}$ verifies in both the calibration and verification intervals.

[35] The coral $\mathrm{Sr} / \mathrm{Ca}-\mathrm{SST}$ record exhibits a strong coherence with IRD SST and HadISST_AI (Figure 10b); however, a running 31-month correlation shows periods where correlation between reconstructed SST and HadISST AI are not significant (Figure 10e). The HadISST1.1 global SST database [Rayner et al., 2003] does not include the number of observations for each grid box; however, HadISST1.1 database includes SST observations from the COADS SST database [Slutz et al., 1985] which includes the number of observations (Figure 10f). The coherence with the gridded HadISST_AI is high for the late twentieth century, which corresponds to a time when the number of SST observations is high (Figure 10f) and when satellites are used to estimate SST around the globe. The misfit between the coral $\mathrm{Sr} / \mathrm{Ca}-$ SST record and the gridded SST record is greatest in the early twentieth century, a time when the number of observations in the gridded SST product is low (Figure 10f). The coral $\mathrm{Sr} / \mathrm{Ca}-\mathrm{SST}$ reconstruction exhibits interannual and decadal-scale fluctuations that exceed those observed in the gridded SST time series (Figure 10b), which may reflect (1) true differences between the SST at a shallow reef site and those averaged over a $1^{\circ}$ grid box or (2) inadequacies in the methodology used to create the gridded SST product when few observations are available. The one exception occurs during the period 1942-1946 when the number of observations sharply increases (Figure 10f) because of the existence of a US naval base in Nouméa at this time. During this period, the residuals between gridded SST and the predicted SST decreases. Therefore careful examination of SST data products is needed when these products are used for calibrating coralbased paleothermometers.

[36] The coherence between coral $\mathrm{Sr} / \mathrm{Ca}$ and SST remains significant for annual averages calculated for a climatological year (April to March). The annual average stack coral $\mathrm{Sr} / \mathrm{Ca}-\mathrm{SST}$ show a strong coherence with both IRD SST and HadISST_AI; however, the annual average reconstructed coral $\mathrm{Sr} / \mathrm{Ca}-\mathrm{SST}$ exhibits larger variability than the HadISST AI (Figure 11); this is similar to the decadalscale differences observed in the filtered monthly anomalies (Figure 10b). The observed differences between the IRD SST and coral Sr/Ca-SST may be due to the presence of negative trend in the IRD SST as previously discussed. A significant $\sim 0.6^{\circ} \mathrm{C}$ warming trend is observed in the annual average coral $\mathrm{Sr} / \mathrm{Ca}-\mathrm{SST}$ for the period $1900-1992(\mathrm{Sr} / \mathrm{Ca}-$ $\operatorname{SST}\left({ }^{\circ} \mathrm{C}\right)=(0.006( \pm 0.003,2 \sigma)$ a year $+10.96( \pm 5.51,2 \sigma))$. The coolest (warmest) years appear to correspond with El Niño (La Niña) events. ENSO events are best described in the instrumental record for the latter half of the twentieth century and the cool years $(1951,1965,1972,1982,1986$, and 1997) correspond with El Niño events when New Caledonia experiences cooler and drier conditions than normal. Conversely, New Caledonia experiences warmer and wetter conditions during La Niña events and the warmer years $(1970,1973,1975,1988$, and 1998) correspond to La Niña events.

\section{Conclusions}

[37] This study assessed the effects of sampling resolution on coral skeletal geochemistry, the reproducibility of coral skeletal geochemistry, and the relation between variations in skeletal geochemistry and SST. In terms of sampling resolution, it was determined that mean coral $\mathrm{Sr} / \mathrm{Ca}$ and $\delta^{18} \mathrm{O}$ values do not change significantly as a function of sampling resolution. The monthly resolved $\mathrm{Sr} / \mathrm{Ca}$ and $\delta^{18} \mathrm{O}$ were able to capture the winter minima and summer maxima and seasonal $\delta^{18} \mathrm{O}$ was able capture summer maxima; however, the winter minima were not always captured. The use of the continuous routing method for coral sampling results in a smoothing of high frequencies (i.e., lunar or tidal) if indeed these signals are present in the coral geochemistry record. The increased sampling resolution produced smaller smoothing intervals thus increasing the resolution of the high/lows of the seasonal cycle and inflating the amplitude of the seasonal cycle; however, the inflation is not linear, but decreases with increasing resolution.

[38] In terms of the reproducibility of coral skeletal geochemistry, multiple tests were performed. First, when the growth direction of the corallites is approximately vertical and the sampling path is parallel to the major growth axis the variability between adjacent parallel sampling paths on the same coral slab is small for coral $\mathrm{Sr} / \mathrm{Ca}$ determinations from Amédée Island, New Caledonia. Second, coral $\mathrm{Sr} / \mathrm{Ca}$ records from parallel cores from the same colony and multiple cores from the same reef are 
highly reproducible and the correlation between the coral $\mathrm{Sr} / \mathrm{Ca}$ records remained significant after removing the annual cycle. These results demonstrate that monthly resolved coral $\mathrm{Sr} / \mathrm{Ca}$ variations from multiple cores from the same coral colony and from the same location are recording the same $\mathrm{Sr} / \mathrm{Ca}$ signal and that environmental variations outweigh biological ones in the monthly resolved $\mathrm{Sr} / \mathrm{Ca}$ signal. The replication of the coral $\mathrm{Sr} / \mathrm{Ca}$ using multiple cores over the twentieth century increases our confidence for a future reconstruction were we will extend the records back to the seventeenth century.

[39] In terms of the fidelity of the coral $\mathrm{Sr} / \mathrm{Ca}-\mathrm{SST}$ relation, it is noted that the coral $\mathrm{Sr} / \mathrm{Ca}$ record exhibits a strong coherence with the in situ SST and gridded SST data products. The coherence with gridded SST is high during the late twentieth century, which corresponds to a time with a high number of observations and the use of remote sensing techniques to estimate SST. The misfit between the coral $\mathrm{Sr} / \mathrm{Ca}-\mathrm{SST}$ record and the gridded SST record is greatest in the early twentieth century, a time when the number of observations in the gridded SST product is low. The monthly coral $\mathrm{Sr} / \mathrm{Ca}-\mathrm{SST}$ reconstruction exhibits interannual and decadal-scale fluctuations that exceed those observed in the gridded SST time series, which may reflect true differences between the SST at a shallow reef site and those averaged over a $1^{\circ}$ grid box or they may reflect inadequacies in the methodology used to create the gridded SST product when few observations are available. Careful examination of the SST data products is needed when they are used for calibrating coral-based paleothermometers. A $\sim 0.6^{\circ} \mathrm{C}$ warming trend is observed in the coral $\mathrm{Sr} / \mathrm{Ca}-\mathrm{SST}$ record.

[40] Acknowledgments. We thank Thierry Corrége and Timothée Ourbak for SST data, Christy Stephans for coral geochemical data from 99-PAA, 92-PAC1, and 92-PAD1, Gary Mitchum for guidance and statistical assistance, Ethan Goddard of the USF Paleoclimatology, Paleoceanography, and Biogeochemistry Laboratory for analytical assistance, and the reviewers for their comments.

\section{References}

Alibert, C., and M. T. McCulloch (1997), Strontium/calcium ratios in modern Porites corals from the Great Barrier Reef as a proxy for sea surface temperature: Calibration of the thermometer and monitoring of ENSO, Paleoceanography, 12(3), 345-363.

Allison, N., and A. A. Finch (2004), High-resolution $\mathrm{Sr} / \mathrm{Ca}$ records in modern Porites lobata corals: Effects of skeletal extension rate and architecture, Geochem. Geophys. Geosyst., 5(5), Q05001, doi:10.1029/2004GC000696.

Alory, G., A. Vega, A. Ganachaud, and M. Despinoy (2006), Influence of upwelling, subsurface stratification, and heat fluxes on coastal sea surface temperature off southwestern New Caledonia, J. Geophys. Res., 111, C07023, doi:10.1029/2005JC003401.

Beck, J. W., R. L. Edwards, E. Ito, F. W. Taylor, J. Récy, F. Rougerie, P. Joannot, and C. Hénin (1992), Sea-surface temperatures from coral skeletal strontium/calcium ratios, Science, 257(5070), 644-647.

Bloomfield, P. (2000), Fourier Analysis of Time Series: An Introduction, 2nd ed., John Wiley, New York.

Briffa, K. R. (1995), Interpreting high-resolution proxy climate data-The example of dendroclimatology, in Analysis of Climate Variability, edited by $\mathrm{H}$. von Storch and A. Navarra, pp. 77-94, Springer, Berlin.

Briffa, K. R., P. D. Jones, J. R. Pilcher, and M. K. Hughes (1988), Reconstructing summer temperatures in northern Fennoscandinavia back to A.D. 1700 using tree-ring data from Scots Pine, Arct. Alp. Res., 20(4), 385-394.

Cohen, A. L., and R. A. Sohn (2004), Tidal modulation of $\mathrm{Sr} / \mathrm{Ca}$ ratios in a Pacific reef coral, Geophys. Res. Lett., 31, L16310, doi:10.1029/ 2004GL020600.

Cook, E. R. (1995), Temperature histories from tree rings and corals, Clim. Dyn., 11, 211-222.

Cook, E. R., and L. A. Kairiukstis (Eds.) (1990), Methods of Dendrochronology: Applications in the Environmental Sciences, Kluwer, Dordrecht, Netherlands.
Corrège, T. (2006), Sea surface temperature and salinity reconstruction from coral geochemical tracers, Palaeogeogr. Palaeoclimatol. Palaeoecol., 232(2-4), 408-428, doi:10.1016/ j.palaeo.2005.10.014

Corrège, T., T. Delcroix, J. Récy, W. Beck, G. Cabioch, and F. Le Cornec (2000), Evidence for stronger El Niño-Southern Oscillation (ENSO) events in a mid-Holocene massive coral, Paleoceanography, 15(4), $465-470$.

Crowley, T. J., T. M. Quinn, and W. T. Hyde (1999), Validation of coral temperature calibrations, Paleoceanography, 14(5), 605-615.

Delcroix, T., and O. Lenormand (1997), ENSO signals in the vicinity of New Caledonia, south western Pacific, Oceanol. Acta, 20(3), 481491.

Felis, T., J. Pätzold, and Y. Loya (2003), Mean oxygen-isotope signatures in Porites spp. corals: Inter-colony variability and correction for extension-rate effects, Coral Reefs, 22(4), 328-336, doi:10.1007/s00338-003-0324-3.

Felis, T., G. Lohmann, H. Kuhnert, S. J. Lorenz, D. Scholz, J. Pätzold, S. A. Al-Rousan, and S. M. Al-Moghrabi (2004), Increased seasonality in Middle East temperatures during the last interglacial period, Nature, 429(6988), 164-168, doi:10.1038/nature02546.

Fritts, H. C. (1976), Tree Rings and Climate, Academic, London.

Fritts, H. C., G. R. Lofgren, and G. A. Gordon (1979), Variations in climate since 1602 as reconstructed from tree rings, Quat. Res., $12(1), 18-46$.

Hendy, E. J., M. K. Gagan, C. A. Alibert, M. T. McCulloch, J. M. Lough, and P. J. Isdale (2002), Abrupt decrease in tropical Pacific sea surface salinity at end of Little Ice Age, Science, 295(5559), 1511-1514, doi:10.1126/ science. 1067693

Hénin, C., and G. R. Cresswell (2005), Upwelling along the western barrier reef of New Caledonia, Mar. Freshwater Res., 56(7), 1005-1010, doi:10.1071/MF04266.
Hénin, C., J.-M. Guillerm, and L. Chabert (1984), Circulation superficielle autour de la Nouvelle-Calédonie, Oceanogr. Trop., 19(2), $113-126$.

Levitus, S., and T. P. Boyer (1994), World Ocean Atlas 1994, vol. 4, Temperature, NOAA Atlas NESDIS, vol. 4, 117 pp., NOAA, Silver Spring, Md.

Linsley, B. K., L. Ren, R. B. Dunbar, and S. S. Howe (2000), El Niño Southern Oscillation (ENSO) and decadal-scale climate variability at $10^{\circ} \mathrm{N}$ in the eastern Pacific from 1893 to 1994: A coral-based reconstruction from Clipperton Atoll, Paleoceanography, 15(3), 322335.

Linsley, B. K., A. Kaplan, Y. Gouriou, J. Salinger, P. B. deMenocal, G. M. Wellington, and S. S. Howe (2006), Tracking the extent of the South Pacific Convergence Zone since the early 1600s, Geochem. Geophys. Geosyst., 7, Q05003, doi:10.1029/2005GC001115.

Lough, J. M. (2004), A strategy to improve the contribution of coral data to high-resolution paleoclimatology, Palaeogeogr. Palaeoclimatol. Palaeoecol., 204(1-2), 115-143, doi:10.1016/S0031-0182 (03)00727-2.

Meibom, A., M. Stage, J. Wooden, B. R. Constantz, R. B. Dunbar, A. Owen, N. Grumet, C. R. Bacon, and C. P. Chamberlain (2003), Monthly strontium/calcium oscillations in symbiotic coral aragonite: Biological effects limiting the precision of the paleotemperature proxy, Geophys. Res. Lett., 30(7), 1418, doi:10.1029/ 2002 GL016864.

Montaggioni, L. F., F. Le Cornec, T. Corrège, and G. Cabioch (2006), Coral barium/calcium record of mid-Holocene upwelling activity in New Caledonia, south-west Pacific, Palaeogeogr. Palaeoclimatol. Palaeoecol., 237(2-4), 436-455, doi:10.1016/j.palaeo.2005.12.018.

Morliere, A., and J. P. Rebert (1986), Rainfall shortage and El Niño-Southern Oscillation in New Caledonia, southwestern Pacific, Mon. Weather Rev., 114(6), 1131-1137.

Nothdurft, L., and G. Webb (2007), Microstructure of common reef-building coral genera Acropora, 
Pocillopora, Goniastrea and Porites: Constraints on spatial resolution in geochemical sampling, Facies, 53(1), 1-26, doi:10.1007/ s10347-006-0090-0.

Ourbak, T., T. Corrège, B. Malaizé, F. Le Cornec, K. Charlier, and J. P. Peypouquet (2006), A high-resolution investigation of temperature, salinity, and upwelling activity proxies in corals, Geochem. Geophys. Geosyst., 7, Q03013, doi:10.1029/2005GC001064.

Paillard, D., L. Labeyrie, and P. Yiou (1996), Macintosh program performs time-series analysis, Eos Trans. $A G U, 77,379$.

Parker, D. E., M. Jackson, and E. B. Horton (1995), The 1961-1990 GISST2.2 sea surface temperature and sea ice climatology, Clim. Res. Tech. Note 63 (CRNT63), Hadley Cent. for Clim. Predict. and Res., Meteorol. Off., Bracknell, U. K.

Pesin, E., S. Blaize, D. Lacoste, M. Argent, and Météo-France (1995), Atlas climatique de la Nouvelle-Caledonie, Météo-France, Nouméa, New Caledonia.

Quinn, T. M., and D. E. Sampson (2002), A multiproxy approach to reconstructing sea surface conditions using coral skeleton geochemistry, Paleoceanography, 17(4), 1062, doi:10.1029/2000PA000528.

Quinn, T. M., F. W. Taylor, T. J. Crowley, and S. M. Link (1996), Evaluation of sampling resolution in coral stable isotope records: A case study using records from New Caledonia and Tarawa, Paleoceanography, 11(5), 529-542.

Quinn, T. M., T. J. Crowley, F. W. Taylor, C. Hénin, P. Joannot, and Y. Join (1998), A multicentury stable isotope record from a New
Caledonia coral: Interannual and decadal sea surface temperature variability in the southwest Pacific since 1657 A.D., Paleoceanography, 13(4), 412-426.

Rayner, N. A., D. E. Parker, E. B. Horton, C. K Folland, L. V. Alexander, D. P. Rowell, E. C. Kent, and A. Kaplan (2003), Global analyses of SST, sea ice, and night marine air temperature since the late nineteenth century, $J$. Geophys. Res., 108(D14), 4407, doi:10.1029/ 2002JD002670.

Reynolds, R. W., and T. M. Smith (1994), Improved global sea surface temperature analyses using optimum interpolation, J. Clim., 7(6), 929-948.

Schrag, D. P. (1999), Rapid analysis of highprecision $\mathrm{Sr} / \mathrm{Ca}$ ratios in corals and othe marine carbonates, Paleoceanography, 14(2), 97-102.

Sinclair, D. J. (2005), Correlated trace element "vital effects" in tropical corals: A new geochemical tool for probing biomineralization, Geochim. Cosmochim. Acta, 69(13), $3265-$ 3284, doi:10.1016/j.gca.2005.02.030.

Slutz, R. J., S. J. Lubker, J. D. Hiscox, S. D. Woodruff, R. L. Jenne, D. H. Joseph, P. M. Steurer, and J. D. Elms (1985), Comprehensive Ocean-Atmosphere Data Set, Release 1, Rep. NTIS PB86-105723, 268 pp., NOAA Environ. Res. Lab., Clim. Res. Program, Boulder, Colo.

Smith, S. V., R. W. Buddemeier, R. C. Redalje, and J. E. Houck (1979), Strontium-calcium thermometry in coral skeletons, Science, 204(27), 404-406.

Smith, T. M., and R. W. Reynolds (2004), Improved extended reconstruction of SST (1854-1997)
J. Clim., 17, 2466-2477, doi:10.1175/1520 0442(2004)017<2466:IEROS >2.0.CO;2.

Solow, A. R., and A. Huppert (2004), A potential bias in coral reconstruction of sea surface temperature, Geophys. Res. Lett., 31, L06308, doi:10.1029/2003GL019349.

Stephans, C. L., T. M. Quinn, F. W. Taylor, and T. Corrège (2004), Assessing the reproducibility of coral-based climate records, Geophys. Res. Lett., 31, L18210, doi:10.1029/ 2004GL020343.

Weber, J. N. (1973), Incorporation of strontium into reef coral skeletal carbonate, Geochim Cosmochim. Acta, 37(9), 2173-2190.

Wigley, T. M. L., K. R. Briffa, and P. D. Jones (1984), On the average value of correlated time series, with applications in dendroclimatology and hydrometeorology, J. Clim. Appl. Meteorol., 23(2), 201-213.

York, D., and N. M. Evensen (2004), Unified equations for the slope, intercept and standard errors of the best straight line, Am. J. Phys. 72(3), 367-375, doi:10.1119/1.1632486.

K. L. DeLong, College of Marine Science, University of South Florida, 140 7th Avenue South, St. Petersburg, FL 33701, USA. (kdelong@marine. usf.edu)

T. M. Quinn and F. W. Taylor, Institute for Geophysics, Jackson School of Geosciences, University of Texas at Austin, 10100 Burnet Road, Austin, TX 78758-4445, USA. 